\title{
Synthesis, Photophysical, Photochemical, and Redox Properties of Nitrospiropyrans Substituted with Ru or Os Tris(bipyridine) Complexes
}

\author{
Ron T. F. Jukes, ${ }^{\dagger}$ Biljana Bozic, ${ }^{\ddagger}$ František Hartl, ${ }^{*, \dagger}$ Peter Belser, ${ }^{\ddagger}$ and Luisa De Cola ${ }^{*,+\$}$ \\ Van't Hoff Institute for Molecular Sciences, University of Amsterdam, Nieuwe Achtergracht 166, \\ 1018 WS Amsterdam, The Netherlands, Institute of Inorganic Chemistry, University of Fribourg, \\ Pérolles CH-1700 Fribourg, Switzerland, and Physikalisches Institut, Westfälische \\ Wilhelms-Universität, Mendelstrasse 7, 48149 Münster, Germany
}

\begin{abstract}
Photochromic nitrospiropyrans substituted with 2,2'-bipyridine (bpy), $\left[\mathrm{Ru}(\mathrm{bpy})_{3}\right]^{2+}$, and $\left[\mathrm{Os}(\mathrm{bpy})_{3}\right]^{2+}$ groups were synthesized, and their photophysical, photochemical, and redox properties investigated. Substitution of the spiropyran with the metal complex moiety results in strongly decreased efficiency of the ring-opening process as a result of energy transfer from the excited spiropyran to the metal center. The lowest excited triplet state of the spiropyran in its open merocyanine form is lower in energy than the excited triplet MLCT level of the $\left[R u(b p y)_{3}\right]^{2+}$ moiety but higher in energy than for $\left[\mathrm{Os}(\mathrm{bpy})_{3}\right]^{2+}$, resulting in energy transfer from the excited ruthenium center to the spiropyran but inversely in the osmium case. The open merocyanine form reduces and oxidizes electrochemically more easily than the closed nitrospiropyran. Like photoexcitation, electrochemical activation also causes opening of the spiropyran ring by first reducing the closed form and subsequently reoxidizing the corresponding radical anion in two wellresolved anodic steps. Interestingly, the substitution of the spiropyran with a Ru or Os metal center does not affect the efficiency of this electrochemically induced ring-opening process, different from the photochemical path.
\end{abstract}

\section{Introduction}

In recent years, much effort has been devoted to the development of photochromic materials, which are systems existing in two forms that can be interconverted using light of different wavelengths as a stimulus. ${ }^{1-3}$ The two forms generally differ in their chemical and physical properties such as, e.g., shape, color, and reactivity. The interest in these compounds arises from their potential application in molecular electronics and data storage ${ }^{4-7}$ first suggested by Hirshberg in $1956 .{ }^{8}$

\footnotetext{
* To whom correspondence should be addressed. E-mail: decola@unimuenster.de (L.D.C.); hartl@science.uva.nl (F.H.).

University of Amsterdam.

$\doteqdot$ University of Fribourg.

$\S$ Westfälische Wilhelms-Universität.

(1) Crano, J. C.; Guglielmetti, R. J. Organic Photochromic and Thermochromic Compounds vol. 1: Photochromic Families; Kluwer: Dordrecht, 1999

(2) Dürr, H.; Bouas-Laurent, H. Photochromism: Molecules and Systems; Elsevier: Amsterdam, 2003

(3) Feringa, B. L. Molecular Switches; Wiley-VCH: Weinheim, 2001.

(4) Raymo, F. M. Adv. Mater. 2002, 14, 401-414.

(5) Joachim, C.; Gimzewski, J. K.; Aviram, A. Nature 2000, 408, 541548.

(6) Irie, M. E. Chem. Rev. 2000, 100.

(7) Balzani, V.; Credi, A.; Venturi, M. ChemPhysChem 2003, 4, 49-59.

(8) Hirshberg, Y. J. Am. Chem. Soc. 1956, 78, 2304-2312.
}

Photochromic molecules can also be incorporated into larger systems to induce properties they do not possess by themselves. One application that recently has attracted a lot of interest is the possibility to use photochromic molecules in energy transfer switching. This function can be achieved by combining a remote chromophore with a photochromic molecule that acts as an energy acceptor only in one of its two forms. In this way, energy transfer from the chromophore to the photochromic moiety can be reversibly switched "on" and "off" by converting the photochromic part. The two forms of the photochromic molecule can be distinguished by changes in the luminescence of the initially excited chromophore. This concept has been demonstrated in systems where the two functionalities are present as separate molecules in solution ${ }^{9,10}$ or are combined in a single molecule. ${ }^{11-16}$

(9) Raymo, F. M.; Giordani, S. Org. Lett. 2001, 3, 1833-1836.

(10) Kozlov, D. V.; Castellano, F. N. J. Phys. Chem. A 2004, 108, 1061910622.

(11) Bahr, J. L.; Kodis, G.; De La Garza, L.; Lin, S.; Moore, A. L.; Moore, T. A.; Gust, D. J. Am. Chem. Soc. 2001, 123, 7124-7133.

(12) Guo, X.; Zhang, D.; Zhou, Y.; Zhu, D. J. Org. Chem. 2003, 68, 56815687.

(13) Song, L.; Jares-Erijman, E. A.; Jovin, T. M. J. Photochem. Photobiol. A: Chem. 2002, 150, 177-185. 
Scheme 1. Simplified Energy Diagrams for the Proposed Switchable DBA System. Left: Long-Range Energy Transfer Occurs between the Donor (D) and Acceptor (A). The Bridge (B) Does Not Facilitate the Process. Right: Efficient Energy Transfer Occurs between D and A through B

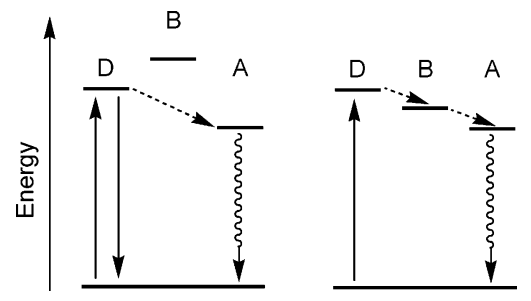

A more advanced approach is to implement the photochromic molecule as a bridge between an energy donor and acceptor, switching the energy transfer "on" and "off" by reversibly converting the bridge. By using a luminescent acceptor, the state of the photochromic bridge can be distinguished by changes in the emission. So far, two examples of such a system have been reported in the literature. In the first one, an anthracene energy donor and a Coumarin energy acceptor are linked by a photochromic fulgide bridge. ${ }^{17}$ Recently, we published a system in which a $\left[\mathrm{Ru}(\mathrm{bpy})_{3}\right]^{2+}$ energy donor and an $\left[\mathrm{Os}(\mathrm{bpy})_{3}\right]^{2+}$ energy acceptor are bridged by a dithienylcyclopentene molecular switch. ${ }^{18}$ Both donor-bridge-acceptor (DBA) systems are based on the principle that in one state the lowest-lying energy levels of the photochromic systems lies between those of the donor and the acceptor, thereby facilitating the energy transfer, while in the other state, the energy levels of the photochromic unit lie below those of the termini, so that excitation energy is transferred to the photochromic bridge and no emission from the acceptor is observed.

A disadvantage of systems of this type is that, in the trapping state, energy is transferred to the photochromic moiety that can consequently convert to the parent form. Therefore, monitoring the occurrence or absence of energy transfer cannot be used as a means for nondestructive readout, as the electronic excitation affects the state of the system.

A better, and generally more elegant solution, concerns the creation of a donor-switch-acceptor triad in which energy transfer from the donor to the acceptor occurs either only in one of the two forms, or in both forms, but significantly more efficiently in one of them.

One way to achieve this goal would be to create a system in which in one state the energy levels of the photochromic bridge lie above those of the donor and acceptor, and energy transfer, if any, takes place by means of a super-exchange mechanism, while in the other state, the levels of the bridge are between those of donor and acceptor, resulting in a hopping mechanism for the energy transfer (see Scheme 1). ${ }^{19}$ The state of the system can then be recognized by monitoring

(14) Jin, M.; Lu, R.; Bao, C. Y.; Xu, T. H.; Zhao, Y. Y. Opt. Mater. 2004, $26,85-88$

(15) Kawai, T.; Sasaki, T.; Irie, M. Chem. Commun. 2001, 711-712.

(16) Ko, C. C.; Wu, L. X.; Wong, K. M. C.; Zhu, N.; Yam, V. W. W. Chem. Eur. J. 2004, 10, 766-776.

(17) Walz, J.; Ulrich, K.; Port, H.; Wolf, H. C.; Wonner, J.; Effenberger, F. Chem. Phys. Lett. 1993, 213, 321-324.

(18) Jukes, R. T. F.; Adamo, V.; Hartl, F.; Belser, P.; De Cola, L. Coord. Chem. Rev. 2005, 249, 1327-1335.
Scheme 2. Photochromic Interconversion of a Typical Spiropyran
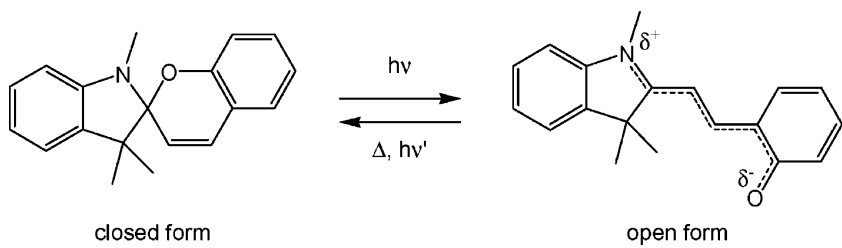

the emission of the acceptor upon excitation of the donor. In such a system, the bridge never becomes an energy trap, and hence, excitation of the donor will not strongly affect the state of the switch. Ideally, the excited state of the bridge that mediates the energy transfer should be nonreactive. Conversion of the bridge should then be achieved by direct excitation to a different, higher-lying excited state. Only then can true nondestructive readout be achieved.

Another property that can be used to control the efficiency of the energy transfer is a large difference in the extent of conjugation over the bridge between the two forms of the photochromic molecule. Better conjugated bridges have a lower attenuation factor, which results in a higher energy transfer rate. Ideally, the photochromic moiety used should exhibit both the difference in energy levels and in conjugation between the two forms in order to maximize the effects.

Spiropyrans are among the most intensively investigated classes of photochromic molecules. ${ }^{20-22}$ Their photochromic properties were first recognized by Fischer and Hirshberg in $1952 .{ }^{23}$ It has been shown that irradiation of a spiropyran molecule with UV light causes cleavage of the bond between the spiro-carbon and oxygen, forcing the molecule to open up (see Scheme 2). At room temperature, the open form reverts thermally to the closed one. The ring-closure process can also be induced photochemically, by irradiation with visible light.

In the closed form, the conjugation of the molecule is broken over the spiro-carbon atom, the two perpendicular halves showing very little interaction. ${ }^{24,25}$ Consequently, the closed molecule is colorless. As soon as the $\mathrm{C}-\mathrm{O}$ bond is broken, the system adapts a planar merocyanine form stabilized by $\pi$-conjugation over the entire molecule.

Instead of "naked" spiropyrans, numerous studies dealt with so-called nitrospiropyrans having a nitro substituent in the $6^{\prime}$ position. The reason for this derivatization is that spiropyrans of this class show higher quantum yields for ring opening and their merocyanine open forms close thermally more slowly than their unsubstituted derivatives. ${ }^{26}$

We decided to employ $\left[\mathrm{Ru}(\mathrm{bpy})_{3}\right]^{2+}$ and $\left[\mathrm{Os}(\mathrm{bpy})_{3}\right]^{2+}$ (bpy $=2,2^{\prime}$-bipyridine) complexes and to couple them directly

(19) Jortner, J.; Bixon, M. Electron Transfer - From Isolated Molecules to Biomolecules, Part One; John Wiley and Sons: New York, 1999; Vol. 106.

(20) Guglielmetti, R. In Photochromism: Molecules and Systems, 2nd ed.; Dürr, H., Bouas-Laurent, H., Eds.; Elsevier: Amsterdam, 2003; pp 314-466, and references therein.

(21) Bertelson, R. C. In Organic Photochromic and Thermochromic Compounds; Crano, J. C., Guglielmetti, R. J., Eds.; Plenum: New York, 1999; Vol. 1, pp 11-83, and references therein.

(22) Berkovic, G.; Krongauz, V.; Weiss, V. Chem. Rev. 2000, 100, 17411753, and references therein.

(23) Fischer, E.; Hirshberg, Y. J. Chem. Soc. 1952, 4522-4524.

(24) Appriou, P.; Guglielmetti, R.; Garnier, F. J. Photochem. 1978, 8, 145165.

(25) Minkin, V. I. Chem. Rev. 2004, 104, 2751-2776. 
Chart 1. Selected Investigated Compounds and their Abbreviations

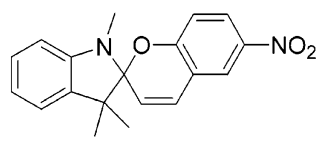

1c
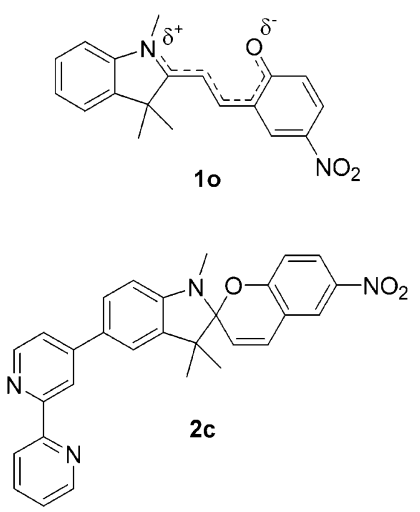
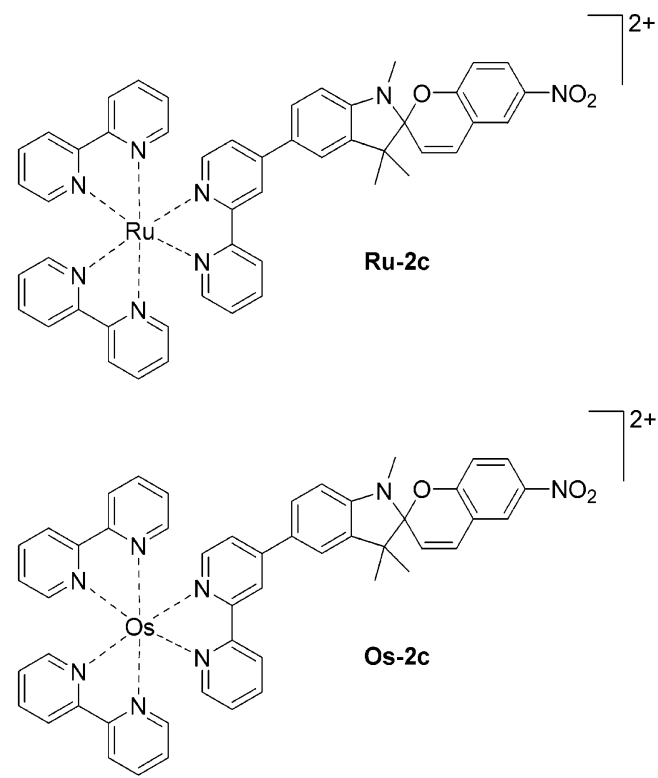

to the well-known spiropyran photochromic system to establish whether they fulfill the requirements for the envisaged type of switchable DBA triads.

In this paper, we report the synthesis, electrochemical, photophysical, and photochemical properties of nitrospiropyrans functionalized with $\left[\mathrm{Ru}(\mathrm{bpy})_{3}\right]^{2+}$ and $\left[\mathrm{Os}(\mathrm{bpy})_{3}\right]^{2+}$ substituents. Their properties were compared to those of the corresponding bpy-functionalized nitrospiropyran.

\section{Experimental Section}

Syntheses of metal complexes were carried out under a slight positive pressure of argon. Chemicals and reagent grade products for syntheses were obtained from Fluka, Aldrich, and Acros Chemicals and used without further purification. 1,3,3-Trimethylindolino-6'-nitrobenzopyrylospiran (1c) was purchased from TCI Europe. $\mathrm{Bu}_{4} \mathrm{NPF}_{6}$ electrolyte was recrystallized twice from absolute ethanol and dried under vacuum at $80^{\circ} \mathrm{C}$ before use. Solvents for syntheses and electrochemical experiments were distilled from appropriate drying agents, ${ }^{27}$ except dimethylformamide (DMF), which was purchased as a dry solvent packaged under nitrogen atmosphere, and used as such. All spectroscopic experiments were carried out in spectroscopic grade solvents purchased from Merck. Purification with preparative plates was done using glass sheets recoated with silica gel $60 \mathrm{~F}_{254}$ with a layer thickness of $2 \mathrm{~mm}$ purchased from Merck. Thin-layer chromatography (TLC) was performed using aluminum sheets coated with silica gel $60 \mathrm{~F}_{254}$ purchased from Merck.

The bpy-functionalized spiropyran ligand $\mathbf{2 c}$ (see Chart 1) was prepared following the protocol developed previously. ${ }^{28}$ The procedures for the syntheses of the metal precursors $\left[\mathrm{Ru}(\mathrm{bpy})_{2} \mathrm{Cl}_{2}\right] \cdot$ $\mathrm{H}_{2} \mathrm{O}$ and $\left[\mathrm{Os}(\text { bpy })_{2} \mathrm{Cl}_{2}\right.$ ] were adapted from a general preparation procedure for compounds $\left[\mathrm{RuL}_{2} \mathrm{Cl}_{2}\right](\mathrm{L}=\alpha$-diimine $) .{ }^{29,30}$

(26) Bercovici, T.; Heiligman-Rim, R.; Fischer, E. Mol. Photochem. 1969, $1,23-55$.

(27) Armarego, W. L. F.; Chai, C. Purification of Laboratory Chemicals, 5th ed.; Elsevier: Amsterdam, 2003.

(28) Querol, M.; Bozic, B.; Salluce, N.; Belser, P. Polyhedron 2003, 22, 655-664.

(29) Dwyer, F. P.; Hogarth, J. W. In Inorganic Syntheses; McGraw-Hill: New York, 1957; Vol. 5, pp 206-207.
$\left[\mathrm{Ru}(\mathrm{bpy})_{2}(2 \mathrm{c})\right]\left(\mathrm{PF}_{6}\right)_{2}, \mathbf{R u}-2 \mathrm{c}$ (see Chart 1). A solution of $2 \mathrm{c}$ (78 mg, $0.150 \mathrm{mmol})$ and $\left[\mathrm{Ru}(\mathrm{bpy})_{2} \mathrm{Cl}_{2}\right] \cdot 2 \mathrm{H}_{2} \mathrm{O}(57 \mathrm{mg}, 0.150 \mathrm{mmol})$ in 2-methoxyethanol/ $\mathrm{H}_{2} \mathrm{O}(10 \mathrm{~mL} ; 95: 5$, v/v) was refluxed for $5 \mathrm{~h}$ under an argon atmosphere. After cooling, the solvent was distilled off under vacuum and the residue was treated with an aqueous solution of $10 \% \mathrm{NH}_{4} \mathrm{PF}_{6}$. The precipitate was collected by filtration and washed with water. The crude product was purified by plate chromatography $\left(\mathrm{SiO}_{2}\right)$, using a mixture of $\mathrm{MeCN} / \mathrm{MeOH} / \mathrm{KNO}_{3}$ solution (40:10:10; volume ratios; the $\mathrm{KNO}_{3}$ solution was prepared by dissolution of $1 \mathrm{~g}$ of $\mathrm{KNO}_{3}$ in $10 \mathrm{~mL}$ of $\mathrm{H}_{2} \mathrm{O}$ ) as eluent. The main red band was scraped off and washed out by acetone/1\% $\mathrm{NH}_{4}$ $\mathrm{PF}_{6}$. After adding water, the organic solvent was removed and an orange red powder was collected by filtration. Yield $95 \mathrm{mg}, 54 \%$. ${ }^{1} \mathrm{H}$ NMR (500 MHz, MeCN- $d_{3}$ ): $\delta 1.22(\mathrm{~s}, 3 \mathrm{H}, \mathrm{H}-\mathrm{C}(9)), 1.35$ (s, $3 \mathrm{H}, \mathrm{H}-\mathrm{C}(10)), 2.81(\mathrm{~s}, 3 \mathrm{H}, \mathrm{H}-\mathrm{C}(8)), 5.96\left(\mathrm{~d}, 1 \mathrm{H},{ }^{3} \mathrm{~J}=10.4\right.$, $\left.\mathrm{H}-\mathrm{C}\left(3^{\prime}\right)\right), 6.73\left(\mathrm{dd}, 2 \mathrm{H},{ }^{3} J=7.3,{ }^{3} J=7.1, \mathrm{H}-\mathrm{C}\left(8^{\prime}\right)\right.$ and $\left.\mathrm{H}-\mathrm{C}(7)\right)$, $7.09\left(\mathrm{~d}, 1 \mathrm{H},{ }^{3} \mathrm{~J}=9.9, \mathrm{H}-\mathrm{C}\left(4^{\prime}\right)\right), 7.38-7.42\left(\mathrm{~m}, 5 \mathrm{H}, \mathrm{H}-\mathrm{C}\left(2^{\mathrm{IV}}\right)\right.$, $\mathrm{H}-\mathrm{C}\left(2^{\mathrm{V}}\right), \mathrm{H}-\mathrm{C}\left(8^{\prime \prime}\right), \mathrm{H}-\mathrm{C}\left(8^{\mathrm{IV}}\right)$ and $\left.\mathrm{H}-\mathrm{C}\left(8^{\mathrm{V}}\right)\right), 7.61-7.62(\mathrm{~m}, 1 \mathrm{H}$, $\left.\mathrm{H}-\mathrm{C}\left(2^{\prime \prime}\right)\right), 7.67\left(\mathrm{bd}, 1 \mathrm{H},{ }^{4} \mathrm{~J}=2.0, \mathrm{H}-\mathrm{C}\left(4^{\prime \prime}\right)\right), 7.73-7.82(\mathrm{~m}, 7 \mathrm{H}$, $\mathrm{H}-\mathrm{C}\left(3^{\mathrm{IV}}\right), \mathrm{H}-\mathrm{C}\left(3^{\mathrm{V}}\right), \mathrm{H}-\mathrm{C}(4), \mathrm{H}-\mathrm{C}(6), \mathrm{H}-\mathrm{C}\left(9^{\prime \prime}\right), \mathrm{H}-\mathrm{C}\left(9^{\mathrm{IV}}\right)$ and $\left.\mathrm{H}-\mathrm{C}\left(9^{\mathrm{V}}\right)\right), 7.99\left(\mathrm{ddd}, 1 \mathrm{H},{ }^{3} J=8.9,{ }^{3} \mathrm{~J}=2.8,{ }^{4} \mathrm{~J}=0.4, \mathrm{H}-\mathrm{C}\left(7^{\prime}\right)\right)$, 8.03-8.07 (m, 5H, H-C $\left(4^{\mathrm{IV}}\right), \mathrm{H}-\mathrm{C}\left(4^{\mathrm{V}}\right), \mathrm{H}-\mathrm{C}\left(10^{\prime \prime}\right), \mathrm{H}-\mathrm{C}\left(10^{\mathrm{IV}}\right)$ and $\left.\mathrm{H}-\mathrm{C}\left(10^{\mathrm{V}}\right)\right), 8.10\left(\mathrm{~d}, 1 \mathrm{H},{ }^{4} \mathrm{~J}=2.8, \mathrm{H}-\mathrm{C}\left(5^{\prime}\right)\right), 8.48-8.51(\mathrm{~m}$, $4 \mathrm{H}, \mathrm{H}-\mathrm{C}\left(1^{\mathrm{IV}}\right), \mathrm{H}-\mathrm{C}\left(1^{\mathrm{V}}\right), \mathrm{H}-\mathrm{C}\left(7^{\mathrm{IV}}\right)$ and $\left.\mathrm{H}-\mathrm{C}\left(7^{\mathrm{V}}\right)\right), 8.68-8.70(\mathrm{~m}$, $2 \mathrm{H}, \mathrm{H}-\mathrm{C}\left(1^{\prime \prime}\right)$ and $\left.\mathrm{H}-\mathrm{C}\left(7^{\prime \prime}\right)\right) .{ }^{13} \mathrm{C}$ NMR $\left(125 \mathrm{MHz}, \mathrm{MeCN}-d_{3}\right): \delta$ 19.9, 25.9, 29.0, 52.9, 108.4, 116.1, 119.90, 121.5, 121.7, 121.8, $123.7,124.4,125.1,125.1,125,2,126.6,127.2,128.4,128.4,128.4$, $128.9,129.5,138.5,138.6,138.6,138.8,142.2,150.6,151.1,152.0$, $152.5,152.5,152.5,152.6,152.6,157.9,157.9,157.9,157.9,158.2$, 160.1. HRMS (ESI), m/z: $\left[\mathrm{M}-2 \mathrm{PF}_{6}\right]^{2+}$ calcd for $\mathrm{C}_{49} \mathrm{H}_{40} \mathrm{~N}_{8} \mathrm{O}_{3}-$ $\mathrm{Ru}(102)$ : 445.1128; found: 445.1127.

[Os(bpy $\left.)_{2}(\mathbf{2 c})\right]\left(\mathbf{P F}_{6}\right)_{2}$, Os-2c (see Chart 1). A solution of 2c $(60 \mathrm{mg}, 0.126 \mathrm{mmol})$ and $\left[\mathrm{Os}(\mathrm{bpy})_{2} \mathrm{Cl}_{2}\right](72 \mathrm{mg}, 0.126 \mathrm{mmol})$ in ethylene glycol/ $\mathrm{H}_{2} \mathrm{O}(5 \mathrm{~mL} ; 95: 5, \mathrm{v} / \mathrm{v})$ was refluxed at $150^{\circ} \mathrm{C}$ for $4 \mathrm{~h}$ under an argon atmosphere. After cooling, the solvent was distilled off and the residue was treated with an aqueous solution of $10 \% \mathrm{NH}_{4} \mathrm{PF}_{6}$. The precipitate formed was collected by filtration and washed with water. The crude product was purified by plate

(30) Lay, P. A.; Sargeson, A. M.; Taube, H. In Inorganic Syntheses; Shreeve, J. M., Ed.; Wiley: New York, 1986; Vol. 24, pp 291-299. 
Scheme 3. Synthesis of the Spiropyran Ligand $2 \mathrm{c}$ and the Corresponding Metal Complexes Ru-2c and Os-2c<smiles>Brc1ccc(-c2ccnc(-c3ccccn3)c2)cc1</smiles>

3

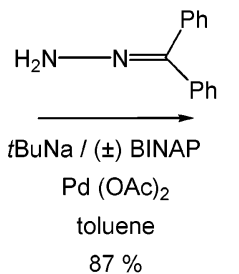

$87 \%$<smiles>c1ccc(C(=NNc2ccc(-c3ccnc(-c4ccccc4)c3)cc2)c2ccccc2)cc1</smiles>

4

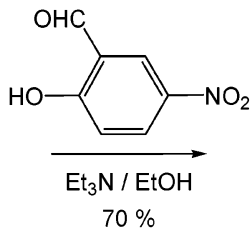

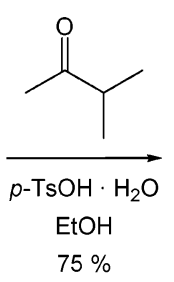<smiles>CC1=Nc2ccc(-c3ccnc(-c4ccccn4)c3)cc2C1(C)C</smiles>

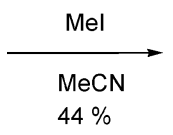

$\left[\mathrm{M}(\mathrm{bpy})_{2} \mathrm{Cl}_{2}\right]$ $\mathrm{NH}_{4} \mathrm{PF}_{6}$<smiles>C=C1N(C)c2ccc(-c3ccnc(-c4ccccn4)c3)cc2C1(C)C</smiles>

6<smiles>CN1c2ccc(-c3ccnc(-c4ccccn4)c3)cc2C(C)(C)C12C=Cc1cc([N+](=O)[O-])ccc1O2</smiles>

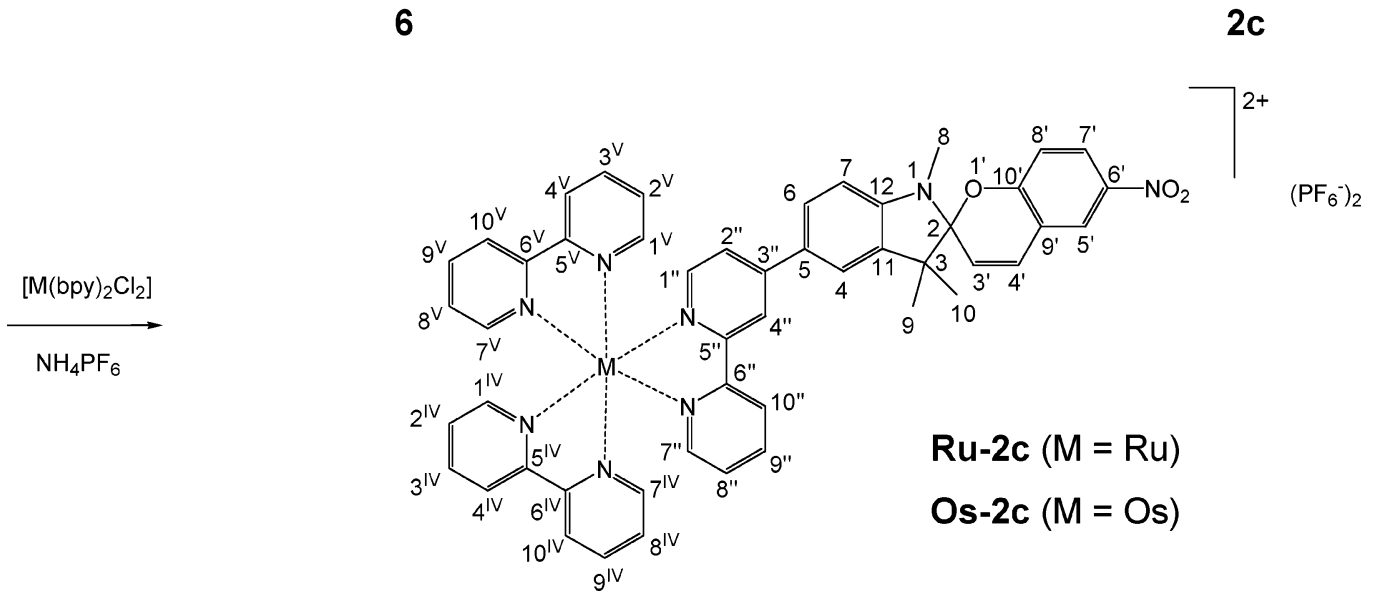

chromatography $\left(\mathrm{SiO}_{2}\right)$, using a mixture of $\mathrm{MeCN} / \mathrm{MeOH} / \mathrm{KNO}_{3}$ solution (40:10:10; volume ratios; the $\mathrm{KNO}_{3}$ solution was prepared by dissolution of $1 \mathrm{~g}$ of $\mathrm{KNO}_{3}$ in $10 \mathrm{~mL}$ of $\mathrm{H}_{2} \mathrm{O}$ ) as eluent. After isolation and repeated precipitation with ammonium hexafluorophosphate, a dark green powder was obtained. Yield $30 \mathrm{mg}, 45 \%$. ${ }^{1} \mathrm{H}$ NMR $\left(500 \mathrm{MHz}, \mathrm{MeCN}-d_{3}\right): \delta 1.22$ (s, 3H, H-C(9)), 1.35 (s, $3 \mathrm{H}, \mathrm{H}-\mathrm{C}(10)), 2.81(\mathrm{~s}, 3 \mathrm{H}, \mathrm{H}-\mathrm{C}(8)), 5.96\left(\mathrm{~d}, 1 \mathrm{H},{ }^{3} \mathrm{~J}=10.4\right.$, $\left.\mathrm{H}-\mathrm{C}\left(3^{\prime}\right)\right), 6.75\left(\mathrm{dd}, 2 \mathrm{H},{ }^{3} J=8.3,{ }^{3} J=8.9, \mathrm{H}-\mathrm{C}\left(8^{\prime}\right)\right.$ and $\left.\mathrm{H}-\mathrm{C}(7)\right)$, $7.09\left(\mathrm{~d}, 1 \mathrm{H},{ }^{3} \mathrm{~J}=9.9, \mathrm{H}-\mathrm{C}\left(4^{\prime}\right)\right), 7.28-7.33\left(\mathrm{~m}, 5 \mathrm{H}, \mathrm{H}-\mathrm{C}\left(2^{\mathrm{IV}}\right)\right.$, $\mathrm{H}-\mathrm{C}\left(2^{\mathrm{V}}\right), \mathrm{H}-\mathrm{C}\left(8^{\prime \prime}\right), \mathrm{H}-\mathrm{C}\left(8^{\mathrm{IV}}\right)$ and $\left.\mathrm{H}-\mathrm{C}\left(8^{\mathrm{V}}\right)\right), 7.51-7.55(\mathrm{~m}, 2 \mathrm{H}$, $\mathrm{H}-\mathrm{C}\left(2^{\prime \prime}\right)$ and $\left.\mathrm{H}-\mathrm{C}\left(4^{\prime \prime}\right)\right), 7.64-7.71\left(\mathrm{~m}, 6 \mathrm{H}, \mathrm{H}-\mathrm{C}\left(3^{\mathrm{IV}}\right), \mathrm{H}-\mathrm{C}\left(3^{\mathrm{V}}\right)\right.$, $\mathrm{H}-\mathrm{C}(4), \mathrm{H}-\mathrm{C}\left(9^{\prime \prime}\right), \mathrm{H}-\mathrm{C}\left(9^{\mathrm{IV}}\right)$ and $\left.\mathrm{H}-\mathrm{C}\left(9^{\mathrm{V}}\right)\right), 7.74\left(\mathrm{dd}, 1 \mathrm{H},{ }^{3} \mathrm{~J}=\right.$ $\left.8.2,{ }^{4} J=2.0, \mathrm{H}-\mathrm{C}(6)\right), 7.83-7.90\left(\mathrm{~m}, 5 \mathrm{H}, \mathrm{H}-\mathrm{C}\left(4^{\mathrm{IV}}\right), \mathrm{H}-\mathrm{C}\left(4^{\mathrm{V}}\right)\right.$, $\mathrm{H}-\mathrm{C}\left(10^{\prime \prime}\right), \mathrm{H}-\mathrm{C}\left(10^{\mathrm{IV}}\right)$ and $\left.\mathrm{H}-\mathrm{C}\left(10^{\mathrm{V}}\right)\right), 7.99\left(\mathrm{dd}, 1 \mathrm{H},{ }^{3} \mathrm{~J}=8.9,{ }^{4} \mathrm{~J}\right.$ $\left.=2.8, \mathrm{H}-\mathrm{C}\left(7^{\prime}\right)\right), 8.09\left(\mathrm{~d}, 1 \mathrm{H},{ }^{3} \mathrm{~J}=8.9,{ }^{3} \mathrm{~J}=2.7, \mathrm{H}-\mathrm{C}\left(5^{\prime}\right)\right), 8.46-$ $8.50\left(\mathrm{~m}, 4 \mathrm{H}, \mathrm{H}-\mathrm{C}\left(1^{\mathrm{IV}}\right), \mathrm{H}-\mathrm{C}\left(1^{\mathrm{V}}\right), \mathrm{H}-\mathrm{C}\left(7^{\mathrm{IV}}\right)\right.$ and $\left.\mathrm{H}-\mathrm{C}\left(7^{\mathrm{V}}\right)\right), 8.66-$ $8.68\left(\mathrm{~m}, 2 \mathrm{H}, \mathrm{H}-\mathrm{C}\left(1^{\prime \prime}\right)\right.$ and $\left.\mathrm{H}-\mathrm{C}\left(7^{\prime \prime}\right)\right) .{ }^{13} \mathrm{C} \mathrm{NMR}(125 \mathrm{MHz}$, $\left.\mathrm{MeCN}-d_{3}\right): \delta 19.9,25.9,29.0,52.9,107.3,108.4,108.4,116.2$, 119.9, 121.6, 121.8, 123.7, 124.7, 125.3, 125.4, 125.4, 126.6, 127.0, $128.8,128.9,128.9,128.9,128.9,129.0,129.1,129.5,137.8,137.8$, $137.9,137.9,137.9,137.9,137.9,138.7,142.2,149.9,151.2,151.2$, 151.6, 151.6, 151.6, 151.7, 151.8, 159.7, 159.9, 159.9, 159.9, 160.0, 160.1. HRMS (ESI), $m / z$ : $\left[\mathrm{M}-2 \mathrm{PF}_{6}\right]^{2+}$ calcd for $\mathrm{C}_{49} \mathrm{H}_{40} \mathrm{~N}_{8} \mathrm{O}_{3}$ Os(192): 490.1414; found: 490.1414.
General Techniques. ${ }^{1} \mathrm{H}$ and ${ }^{13} \mathrm{C}$ NMR spectra were obtained on Bruker Advance DRX-500 (500 MHz for ${ }^{1} \mathrm{H}$ NMR and 125.75 $\mathrm{MHz}$ for ${ }^{13} \mathrm{C}$ ) and Bruker DRX-300 (300.11 MHz for ${ }^{1} \mathrm{H}$ NMR) spectrometers.

Chemical shifts $(\delta)$ are given in ppm, using the solvent itself as internal standard. The coupling constants $(J)$ are given in $\mathrm{Hz}$. The assignment of the NMR signals is referred to the carbon numbering of molecules depicted in Scheme 3.

ESI and high-resolution mass spectra were recorded on a Bruker FTMS 4.7T BioAPEXII spectrometer.

Spectroscopic and photophysical investigations of all compounds were performed at $223 \mathrm{~K}$ using a cryostat to prevent the thermal ring-closure reaction recovering the parent compound. When possible, room-temperature measurements were also performed to determine the effect of the temperature on the results. Transient absorption and UV-vis spectroelectrochemistry experiments were performed exclusively at room temperature.

UV-vis absorption spectra were recorded on Hewlett-Packard 8453 diode-array or software-updated Perkin-Elmer Lambda 5 spectrophotometers, and steady-state emission spectra on a Spex 1680 spectrofluorimeter. Emission spectra were not corrected for the photomultiplier response. Deaerated solutions were prepared by the freeze-pump-thaw technique on a vacuum line. Luminescence quantum yields were determined for optically dilute solutions, 
using aerated solutions of $\left[\mathrm{Ru}(\mathrm{bpy})_{3}\right] \mathrm{Cl}_{2}$ in $\mathrm{H}_{2} \mathrm{O}\left(\varphi_{\mathrm{em}}=0.028\right)^{31}$ or $\left[\mathrm{Os}(\mathrm{bpy})_{3}\right]\left(\mathrm{PF}_{6}\right)_{2}$ in $\mathrm{MeCN}\left(\varphi_{\mathrm{em}}=0.0035\right)^{32}$ as reference where appropriate.

The electronic absorption spectra of $\mathbf{1 0}$ and $\mathbf{2 0}$ were constructed combining data from ${ }^{1} \mathrm{H}$ NMR and UV-vis absorption spectroscopies. The ${ }^{1} \mathrm{H}$ NMR spectra of the parent closed-form molecules $\mathbf{1 c}$ and $\mathbf{2 c}$ were recorded in THF- $d_{8}$ at $223 \mathrm{~K}$. Subsequently, the solution in the NMR tube was irradiated with UV light while the solution was kept cold. ${ }^{1} \mathrm{H}$ NMR spectra were recorded at regular time intervals. The concentration ratio between the open and closed forms in the solution was determined from the relative integrals of the doublet signal for the proton in the position $3^{\prime}$ of the closed form molecule ( $\delta 6.00$ for $1 \mathrm{c}$ and 6.06 for $\mathbf{2 c}$ ), and the doublet signal for the proton in the position $8^{\prime}$ of the open form molecule ( $\delta 6.25$ for $\mathbf{1 0}$ and 6.31 for $\mathbf{2 0}$ ). These particular proton signals do not overlap with any other proton signal. After having achieved a significant degree of conversion, part of the solution was quickly transferred from the cold NMR tube to a $1 \mathrm{~cm}$ quartz cell positioned inside a cryostat precooled to $223 \mathrm{~K}$, using a cold syringe. The quartz cell was partially filled with cold tetrahydrofuran (THF) to dilute the NMR solution to a concentration suitable for the recording of UV-vis absorption spectra. On the basis of the ratio obtained from the ${ }^{1} \mathrm{H}$ NMR measurements, the $\mathrm{UV}-$ vis spectra of the pure open-form photoproducts were constructed from the recorded experimental absorption.

Nanosecond time-resolved absorption spectra were measured using a setup described previously. ${ }^{33}$ The irradiation source was a continuously tunable $(400-700 \mathrm{~nm})$ Coherent Infinity XPO laser ( $2 \mathrm{~ns}$ fwhm). This system is normally operated at $10 \mathrm{~Hz}$, but a repetition rate of $2 \mathrm{~Hz}$ was used to record the spectra of $\mathbf{1 c}$ and $\mathbf{2 c}$ to avoid a significant build-up of $\mathbf{1 0}$ and 2o, respectively, in the solution. A 50\% mirror is used to divide the probe light into sample and reference beams, which greatly improves the signal-to-noise ratio.

Time-resolved emission studies in the nanosecond time domain were performed using the continuously tunable $(400-700 \mathrm{~nm})$ Coherent Infinity XPO laser ( $2 \mathrm{~ns}$ fwhm) as the excitation source. The emitted light was detected using a streak camera (Hamamatsu C5680-21) equipped with an M 5677 sweep unit over a range of $300 \mathrm{~nm}$, or at a single emission wavelength, using a combination of an Oriel monochromator and a Hamamatsu P28 photomultiplier tube, from which the signal was recorded on a Tektronix TDS684B (1 GHz, $5 \mathrm{GS} \mathrm{s}^{-1}$ ) oscilloscope.

For sub-nanosecond time-resolved emission measurements, a single photon counting setup was used. The excitation source consists of a frequency-doubled $(300-340 \mathrm{~nm}, 1 \mathrm{ps}, 3.8 \mathrm{MHz})$ output of a cavity dumped DCM dye laser (Coherent Model 700) that was pumped by a mode-locked Ar-ion laser (Coherent 486 AS Mode Locker, Coherent Innova 200 laser). A microchannel plate photomultiplier (Hamamatsu R3809) was used as the detector.

Photocyclization quantum yields were determined by monitoring the increase of the absorption of the photoproduct in the visible region upon irradiation. The photoconversion was kept below $10 \%$. A high-pressure Oriel Hg-lamp (model 6137) in combination with appropriate interference filters served as the irradiation source. The incidental photon flux was determined before and after each

(31) Nakamaru, K. Bull. Chem. Soc. Jpn. 1982, 55, 2697-2705.

(32) Frank, M.; Nieger, M.; Vögtle, F.; Belser, P.; von Zelewsky, A.; De Cola, L.; Balzani, V.; Barigelletti, F.; Flamigni, L. Inorg. Chim. Acta 1996, 242, 281-291.

(33) Kleverlaan, C. J.; Stufkens, D. J.; Clark, I. P.; George, M. W.; Turner, J. J.; Martino, D. M.; van Willigen, H.; Vlček, A., Jr. J. Am. Chem. Soc. 1998, 120, 10871-10879. measurement, using fresh solutions of Aberchrome $540\left(\varphi_{\lambda}=0.20\right.$ for $313 \mathrm{~nm} \leq \lambda \leq 366 \mathrm{~nm})^{34}$ and Aberchrome 540P $\left(\varphi_{\lambda}=0.178-\right.$ $2.40 \times 10^{-4} \lambda$ for $\left.440 \mathrm{~nm} \leq \lambda \leq 550 \mathrm{~nm}\right)^{35}$ actinometers in toluene.

Cyclic and Osteryoung square-wave voltammograms of $\sim 10^{-4}$ $\mathrm{M}$ parent compounds in $10^{-1} \mathrm{M} \mathrm{Bu}_{4} \mathrm{NPF}_{6}$ electrolyte solution were recorded in a gastight single-compartment three-electrode cell equipped with platinum disk working (apparent surface of 0.42 $\mathrm{mm}^{2}$ ), coiled platinum wire auxiliary, and silver wire pseudoreference electrodes. The cell was connected to a computer-controlled PAR Model 283 potentiostat. All redox potentials are reported against the ferrocene/ferrocenium $\left(\mathrm{Fc} / \mathrm{Fc}^{+}\right)$redox couple used as internal standard. ${ }^{36,37}$

Cyclic voltammetric measurements at low temperature were performed by immersing the electrochemical cell into an acetone/ dry ice bath at ca. $210 \mathrm{~K}$. Redox responses of $\mathbf{1 0}$ and 20 were obtained after having irradiated the precooled samples of $\mathbf{1 c}$ and 2c with UV light for a prolonged period, using a high-pressure Oriel $\mathrm{Hg}$ lamp (model 6137) in combination with the appropriate band filter. The degree of conversion was determined by transferring part of the solution quickly from the cold electrochemical cell to a $1 \mathrm{~cm}$ quartz cell positioned inside a cryostat precooled to $223 \mathrm{~K}$, using a cold syringe. The quartz cell was partially filled with THF to dilute the solution to a concentration suitable for the recording of UV-vis absorption spectra. From the obtained UV-vis absorption spectrum, the ratio between open- and closed-form molecules could be determined.

$\mathrm{UV}-$ vis spectroelectrochemical experiments were performed in an airtight optically transparent thin-layer electrochemical (OTTLE) cell, ${ }^{38}$ equipped with a Pt minigrid working electrode (32 wires $\mathrm{cm}^{-1}$ ) and $\mathrm{CaF}_{2}$ or quartz windows. The controlled-potential electrolyses were carried out with a PA4 potentiostat (EKOM, Czech Republic).

Estimated experimental errors in the reported data are as follows. Absorption and emission maxima $\pm 2 \mathrm{~nm}$; emission lifetimes $\pm 8 \%$; emission quantum yields $\pm 20 \%$; photocyclization quantum yields $\pm 10 \%$, electrode potentials $\pm 5 \mathrm{mV}$.

\section{Results and Discussion}

Syntheses. The reference compound 1c, bpy-functionalized ligand $\mathbf{2 c}$, and corresponding complexes $\left[\mathrm{M}(\mathrm{bpy})_{2}(\mathbf{2 c})\right]$ $(\mathrm{M}=\mathrm{Ru}(\mathbf{R u}-2 \mathbf{c}), \mathrm{M}=\mathrm{Os}(\mathbf{O s}-\mathbf{2} \mathbf{c}))$ in their closed spiropyran forms, as well as open merocyanine form molecule 10 are depicted in Chart 1. Open-form compounds 2o, Ru-2o, and Os-2o (not shown) are related to their corresponding closed forms as $\mathbf{1 0}$ is to $\mathbf{1 c}$.

The preparation of ligand $\mathbf{2 c}$ follows the previously developed protocol ${ }^{28}$ and is outlined in Scheme 3. The $N$-aryl benzophenone hydrazine 4 was prepared by a Pd/BINAP (BINAP $=( \pm)-2,2^{\prime}$-bis(diphenylphosphino)-1,1-binaphthyl)-catalyzed cross-coupling reaction of 4-(4-bromophenyl)-2,2'-bipyridine (3) with 2-(diphenylmethylene) hydrazine. The resulting hydrazone, $\mathbf{4}$, was converted into indol product 5 via an in situ

(34) Heller, H. G.; Langan, J. R. J. Chem. Soc., Perkin Trans. 21981 $341-343$.

(35) Glaze, A. P.; Heller, H. G.; Morgan, C. J.; Oliver, S. N.; Whittall, J. In Xth IUPAC Symposium on Photochemistry: Interlaken, Switzerland, 1984; p 369.

(36) Gritzner, G.; Kůta, J. Pure Appl. Chem. 1984, 56, 461-466.

(37) Pavlishchuk, V. V.; Addison, A. W. Inorg. Chim. Acta 2000, 298, 97-102.

(38) Krejčik, M.; Daněk, M.; Hartl, F. J. Electroanal. Chem. 1991, 317, 179-187. 


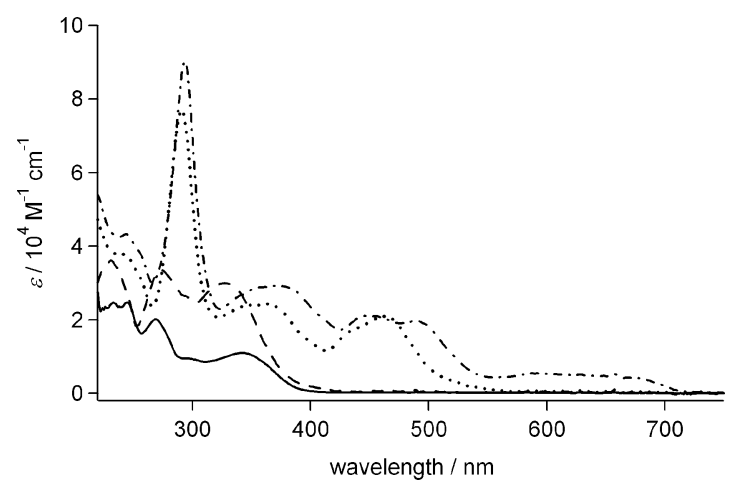

Figure 1. UV-vis absorption spectra of investigated compounds $\mathbf{1 c}(-)$, 2c $(---)$, Ru-2c $(\cdots)$ and Os-2c $(-\cdot-)$ in THF solutions at $223 \mathrm{~K}$.

Table 1. Absorption Maxima and Molar Absorption Coefficients of the Investigated Photochromic Compounds in Their Closed and Open Forms $^{a}$

\begin{tabular}{ll}
\hline compound & \multicolumn{1}{c}{$\lambda_{\max } / \mathrm{nm}\left(\epsilon_{\max } / 10^{4} \mathrm{M}^{-1} \mathrm{~cm}^{-1}\right)$} \\
\hline $\mathbf{1 c}$ & $245(2.5), 269(2.0), 344(1.1)$ \\
$\mathbf{1 0}$ & $248(1.0), 274(0.8), 309(1.0), 371(2.2), 387(2.1)$, \\
& $574(5.7)$ \\
2c & $231(3.6), 273(3.4), 295(2.7), 328(3.0)$ \\
2o & $231(3.2), 277(2.3), 381(2.4), 590(6.2)$ \\
Ru-2c & $291(7.7), 365(2.4), 459(2.1)$ \\
Ru-2o & $291(7.4), 391(2.1), 461(1.7), 603(6.2)$ \\
Os-2c & $294(9.0), 373(2.9), 490(2.0), 591(0.5)$ \\
Os-2o & $294(8.8), 386(3.4), 490(1.9), 605(6.7)$ \\
${ }^{a}$ Conditions; in THF solution, at $223 \mathrm{~K}$.
\end{tabular}

Table 2. Photochemical Ring-Opening Quantum Yields Determined for Investigated Compounds 1c, 2c, Ru-2c, and Os-2 $\mathbf{c}^{a}$

\begin{tabular}{cc}
\hline compound & $\varphi_{334^{b}}$ \\
\hline $\mathbf{1 c}$ & $2.4 \times 10^{-1}$ \\
$\mathbf{2 c}$ & $7.8 \times 10^{-2}$ \\
$\mathbf{R u}-\mathbf{2} \mathbf{c}^{c}$ & $6.5 \times 10^{-3}$ \\
$\mathbf{O s - 2 c ^ { c }}$ & $4.9 \times 10^{-3}$
\end{tabular}

${ }^{a}$ Conditions: in deaerated THF, at $223 \mathrm{~K}$, excitation wavelength $\lambda_{\text {exc }}=$ $334 \mathrm{~nm} .{ }^{b}$ Bubbling oxygen through the solution does not affect the reaction quantum yield. ${ }^{c}$ No photoreaction upon excitation with $450 \mathrm{~nm}$ light.

hydrolysis/Fischer cyclization protocol, using toluene-4sulfonic acid monohydrate $\left(p-\mathrm{TsOH} \cdot \mathrm{H}_{2} \mathrm{O}\right)$ as the hydrolysis agent. A quaternary iodo salt was formed by alkylation of $\mathbf{5}$ with methyl iodide. This salt turns reddish after storage in a fridge, as a result of a conversion to 1,3,3-trimethyl-2methylene-5-(2,2'-bipyridin-4-yl) indoline (6). The condensation reaction between equimolar amounts of Fischer base $\mathbf{6}$ and appropriate salicylaldehyde under basic conditions proceeds rapidly in boiling ethanol, and ligand $\mathbf{2 c}$ is obtained in high yield. The corresponding mononuclear complexes Ru-2c and Os-2c were synthesized by a complexation reaction of ligand $2 \mathrm{c}$ with the complex precursors [Ru(bpy) $\left.{ }_{2} \mathrm{Cl}_{2}\right] \cdot 2 \mathrm{H}_{2} \mathrm{O}$ and $\left[\mathrm{Os}(\mathrm{bpy})_{2} \mathrm{Cl}_{2}\right]$, respectively (see Scheme 3 ). The crude product was purified by plate chromatography $\left(\mathrm{SiO}_{2}\right)$, using a mixture of $\mathrm{MeCN} / \mathrm{MeOH} / \mathrm{KNO}_{3}$ solution (40: 10:10; volume ratios; the $\mathrm{KNO}_{3}$ solution was prepared by dissolution of $1 \mathrm{~g}$ of $\mathrm{KNO}_{3}$ in $10 \mathrm{~mL}$ of $\mathrm{H}_{2} \mathrm{O}$ ) as eluent. Each metal complex was obtained in a pure form as a racemic mixture of $\Delta / \Lambda$ isomers. Synthetic details for the metal complexes are given in the Experimental Section.

UV-Vis Spectral Properties of Parent Spiropyran Compounds. Electronic absorption spectra of model com- pound 1c, ligand $\mathbf{2 c}$, and complexes $\mathbf{R u}-\mathbf{2 c}$ and $\mathbf{O s - 2 c}$ in THF at $223 \mathrm{~K}$ are shown in Figure 1. Absorption maxima and the corresponding molar absorption coefficients, $\epsilon_{\max }$, are reported in Table 1. Absorption spectra of these materials at room temperature and at $223 \mathrm{~K}$ do not differ significantly.

Going from $1 \mathbf{c}$ to $\mathbf{2 c}$, the attachment of the bpy moiety to the spiropyran in position 5 causes a blue-shift of the lowestenergy absorption band between 300 and $400 \mathrm{~nm}$. The fact that the spectrum of $\mathbf{2 c}$ is not simply the sum of the absorptions of 1c and 2,2'-bipyridine shows that the two components interact electronically to a certain extent.

The complexation to the metal ion to form Ru-2c leads to the appearance of several absorption bands not observed for $\mathbf{2 c}$ (see Figure 1). In analogy with the reference complex $\left[\mathrm{Ru}(\mathrm{bpy})_{3}\right]^{2+}$, the bands at 291 and $459 \mathrm{~nm}$ are assigned to spin-singlet bpy-centered ( $\left.{ }^{1} \mathrm{IL}_{\mathrm{bpy}}\right)$ and $\mathrm{Ru}{ }^{\mathrm{II}}$-to-bpy chargetransfer ( $\left.{ }^{1} \mathrm{MLCT}\right)$ transitions, respectively. ${ }^{39}$ There is a fairly strong absorption of the spiropyran subunit in the 330-400 $\mathrm{nm}$ region $\left({ }^{1} \mathrm{IL}_{\mathrm{SP}}\right)$. Compared to $1 \mathbf{c}$ and $\mathbf{2 c}$, the ${ }^{1} \mathrm{IL}_{\mathrm{SP}}$ band in the metal complex is red-shifted. Since there is a minimum absorption of the $\left[\mathrm{Ru}(\mathrm{bpy})_{3}\right]^{2+}$ moiety in the area where the spiropyran absorbs, we can address the photochromic part of the system fairly selectively by exciting into the ${ }^{1} \mathrm{IL}_{\mathrm{SP}}$ transition. On the other hand, the $\left[\mathrm{Ru}(\mathrm{bpy})_{3}\right]^{2+}$ chromophore can be excited selectively by irradiating into the lowest ${ }^{1}$ MLCT band.

The Os-2c complex shows similar UV-vis absorption bands as Ru-2c, with a shift of the ${ }^{1}$ MLCT transitions toward lower energy (see Figure 1). Additional weak and broad bands in the $550-700 \mathrm{~nm}$ are assigned to ${ }^{3}$ MLCT transitions partially allowed as a result of the heavy-atom effect, typical for $\left[\mathrm{Os}(\mathrm{bpy})_{3}\right]^{2+}$-type complexes. ${ }^{40-42}$

All investigated compounds are photoreactive, and the electronic absorption spectra of the photoproducts are discussed in the next section.

Photochemical Spiropyran Ring Opening. Irradiation of all the studied compounds leads to spiropyran ring-opening reactions with dramatic changes in the spectroscopic properties. All photochemical processes have been studied in deaerated THF at $223 \mathrm{~K}$ (see Experimental Section for details), and the quantum yields are reported in Table 2.

Upon irradiation with $334 \mathrm{~nm}$ light, the colorless solution of $\mathbf{1 c}$ in THF turns purple. An intense absorption band rises at $574 \mathrm{~nm}$, and two smaller bands appear at 371 and 387 $\mathrm{nm}$. Going to room temperature, the lowest-energy band shows a pronounced shift of the absorption maximum to 585 $\mathrm{nm}$. The new absorption bands can be attributed to $10^{20}$ The UV-vis absorption spectrum of 10 was obtained by combining ${ }^{1} \mathrm{H}$ NMR and UV-vis absorption data (see Experimental Section for details). The photostationary state reached upon irradiation of 1c with $334 \mathrm{~nm}$ light corresponds to nearly $100 \%$ conversion to $\mathbf{1 0}$.

(39) Juris, A.; Balzani, V.; Barigelletti, F.; Campagna, S.; Belser, P.; von Zelewsky, A. Coord. Chem. Rev. 1988, 84, 85-277.

(40) Demas, J. N.; Crosby, G. A. J. Am. Chem. Soc. 1971, 93, 28412847.

(41) Fujita, I.; Kobayashi, H. Z. Phys. Chem. 1972, 79, 309-314.

(42) Decurtins, S.; Felix, F.; Ferguson, J.; Güdel, H. U.; Ludi, A. J. Am. Chem. Soc. 1980, 102, 4102-4106. 


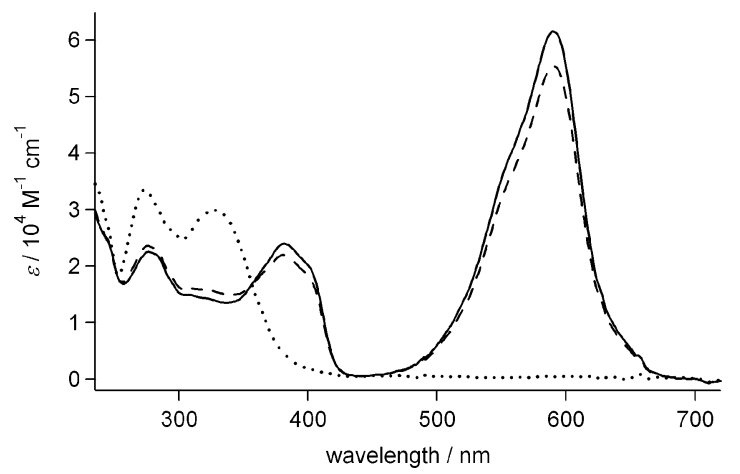

Figure 2. UV-vis absorption spectra in THF solution at $223 \mathrm{~K}$ of $\mathbf{2 c}$ $(\cdots), \mathbf{2 c} / \mathbf{2 o}$ in the photostationary state upon irradiation with $334 \mathrm{~nm}$ light (- -,$- 90 \%$ conversion), and 20 ( - , computed spectrum).

Earlier studies at room temperature showed that the ringopening quantum yield of $\mathbf{1 c}$ depends strongly on the polarity of the solvent, decreasing from 0.83 in methylcyclohexane to 0.24 in acetone and 0.12 in acetonitrile. ${ }^{43}$ Our value in THF of 0.24 fits well into the series. The quantum yield is not influenced by the presence of oxygen. This property is known for 6 '-nitrospiropyrans. ${ }^{44,45}$ Nevertheless, the formation of $\mathbf{1 0}$ from $1 \mathbf{c}$ was shown to occur largely from a triplet state. ${ }^{45}$ The absence of oxygen-dependence for the ringopening quantum yield of $\mathbf{1 c}$ has been explained by a fast formation of an excited-state precursor of $\mathbf{1 0}$ on the triplet potential-energy surface. Upon relaxation to the ground state, part of these precursor molecules turn back to starting compound 1c, while another part proceeds to form 1o. ${ }^{44,45}$

In contrast to this, upon irradiation of spiropyrans that are not substituted with a nitro group, no intersystem crossing (ISC) to a triplet excited state takes place and the formation of open-form molecules occurs exclusively from the singlet excited levels..$^{4-49}$ That the triplet states are not populated upon direct excitation of the system does not mean they are not reactive, however. Using a triplet sensitizer, it was shown, for these spiropyrans, that ring-opening can also occur from a triplet excited state. ${ }^{50}$

Similar results were obtained for $\mathbf{2 c}$. An intense band rises at $590 \mathrm{~nm}(599 \mathrm{~nm}$ at room temperature) and a smaller one at $381 \mathrm{~nm}$, while the band at $328 \mathrm{~nm}$ disappears (see Figure 2). Also in this case, the new bands arise from the formation of the open-form 2o. The electronic absorption spectrum of 2o, shown in Figure 2, was constructed as for 1o. Using the computed spectrum, we have proved that prolonged irradiation of $\mathbf{2 c}$ with $334 \mathrm{~nm}$ light results in a photostationary state corresponding to $90 \%$ conversion of $\mathbf{2 c}$ to $\mathbf{2 0}$.

For $\mathbf{2 c}$, the ring-opening quantum yield is almost four times lower compared to that of $\mathbf{1 c}$ (see Table 2). This result

(43) Görner, H. Phys. Chem. Chem. Phys. 2001, 3, 416-423.

(44) Görner, H.; Atabekyan, L. S.; Chibisov, A. K. Chem. Phys. Lett. 1996, 260, 59-64.

(45) Görner, H. Chem. Phys. Lett. 1998, 282, 381-390.

(46) Lenoble, C.; Becker, R. S. J. Photochem. 1986, 34, 83-88.

(47) Ernsting, N. P. Chem. Phys. Lett. 1989, 159, 526-531.

(48) Zhang, J. Z.; Schwartz, B. J.; King, J. C.; Harris, C. B. J. Am. Chem. Soc. 1992, 114, 10921-10927.

(49) Rini, M.; Holm, A. K.; Nibbering, E. T. J.; Fidder, H. J. Am. Chem. Soc. 2003, 125, 3028-3034.

(50) Bercovici, T.; Fischer, E. J. Am. Chem. Soc. 1964, 86, 5687-5688. is noteworthy, as the transition involved in the ring-opening process is commonly localized on the pyran part of the molecule. ${ }^{51-53}$ Our results show that substitution of the indoline half of the spiropyran with a group like bpy can nevertheless have a pronounced effect on this process.

The photoconversion of $\mathbf{R u - 2 c}$ to $\mathbf{R u - 2 0}$ gives rise to new structured absorption bands at 391 and $603 \mathrm{~nm}(607 \mathrm{~nm}$ at room temperature), while the composed band at $365 \mathrm{~nm}$ disappears (see Figure 3). Therefore, the band at $603 \mathrm{~nm}$ is assigned to ${ }^{1} \mathrm{IL}_{\mathrm{SP}}$ transitions in $\mathbf{R u - 2 o}$. The ${ }^{1} \mathrm{IL}_{\mathrm{bpy}}$ band at $291 \mathrm{~nm}$ and the ${ }^{1}$ MLCT band at $459 \mathrm{~nm}$, which correspond to electronic transitions localized on the $\left[\mathrm{Ru}(\mathrm{bpy})_{3}\right]^{2+}$ moiety, vary only little upon conversion.

Upon conversion of the osmium complex to Os-2o, new bands rise at 386 and $605 \mathrm{~nm}$ (609 $\mathrm{nm}$ at room temperature), while the band at $373 \mathrm{~nm}$ disappears. The bands at 294 and $490 \mathrm{~nm}$, which correspond to transitions localized on the $\left[\mathrm{Os}(\mathrm{bpy})_{3}\right]^{2+}$ moiety, are again hardly affected by the spiropyran ring-opening. It is interesting to note that ringopening occurs for $\mathbf{R u - 2 c}$ and $\mathbf{O s - 2 c}$ upon excitation into the ${ }^{1} \mathrm{IL}_{\mathrm{SP}}$ bands in the $330-400 \mathrm{~nm}$ region, while excitation into the ${ }^{1}$ MLCT transitions around $460 \mathrm{~nm}$ does not induce any photoreactivity.

The UV-vis spectra document that, for both the ruthenium and osmium complexes, the photochromic spiropyran and metal-bpy subunits are electronically fairly independent, as also confirmed by the other results (see following sections).

The ring-opening quantum yields of $\mathbf{R u - 2 c}$ and $\mathbf{O s - 2 \mathbf { c }}$ are more than 1 order of magnitude lower than that of $\mathbf{2 c}$ (see Table 2). We attribute this decrease to an energy-transfer process from the reactive spiropyran-localized excited states to the nonreactive metal-to-bpy CT states. This claim is further corroborated by emission and nanosecond transient absorption data (see below). As a consequence of the low ring-opening quantum yields for $\mathbf{R u - 2 c}$ and Os-2c (see Table 2), it was experimentally not feasible to achieve a sufficient degree of conversion inside the NMR tube to determine the ratio between the closed and open forms with acceptable precision from the ${ }^{1} \mathrm{H}$ NMR spectral changes recorded for these systems. Therefore, we may only assume that the molar absorption coefficients of the ${ }^{1} \mathrm{IL}_{\mathrm{SP}}$ band of Ru-2o and Os$\mathbf{2 0}$ around $600 \mathrm{~nm}$ are the same as for $\mathbf{2 0}$. We trust, however, that this assumption is reasonable, as the attachment of the $\left[\mathrm{Ru}(\mathrm{bpy})_{3}\right]^{2+}$ or $\left[\mathrm{Os}(\mathrm{bpy})_{3}\right]^{2+}$ moieties to $\mathbf{2 o}$ causes only a small red-shift of this band and does not affect its shape.

Considering the short distance between the energy donor and acceptor moieties in this case, energy transfer is expected to be an extremely fast process. In recent experiments on donor-acceptor systems that are either separated by a very short spacer or directly coupled, energy transfer is found to occur within a few picoseconds $s^{5-56}$ or even on the subpicosecond $^{57-59}$ time scale. Formation of the open-form

(51) Tyer, N. W., Jr.; Becker, R. S. J. Am. Chem. Soc. 1970, 92, 12891294.

(52) Tyer, N. W., Jr.; Becker, R. S. J. Am. Chem. Soc. 1970, 92, 12951302.

(53) Tinland, B.; Guglielmetti, R.; Chalvet, O. Tetrahedron 1973, 29, 665667. 


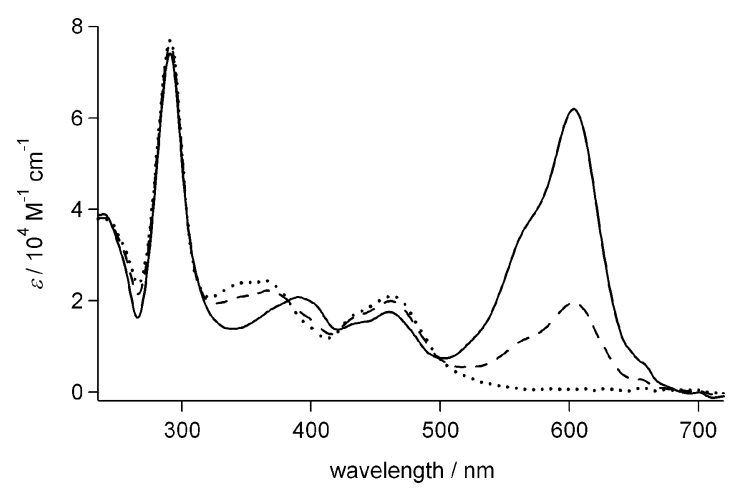

Figure 3. UV-vis absorption spectra in THF solution at $223 \mathrm{~K}$ of $\mathbf{R u - 2 c}$ $(\cdots), \mathbf{R u}-\mathbf{2 c} / \mathbf{R u}-2 \mathrm{o}$ in the photostationary state upon irradiation with 334 nm light (- - , 32\% conversion), and Ru-2o ( - , computed spectrum). species from the first excited singlet state of a spiropyran has also been found to occur on a time scale of only a few picoseconds. ${ }^{48,49,60-64}$ The formation of Ru-2o and Os-2o from their respective closed forms is therefore expected to occur from the excited singlet state, in competition with energy transfer to the metal center.

All the investigated compounds ultimately largely decompose in the process of photoconversion to the open and thermal reconversion to the closed form. This is indicated by the significant decrease of the intensity of the lowestenergy ${ }^{1} \mathrm{IL}_{\mathrm{SP}}$ absorption band in the UV region. We did not study this photodegradation in detail.

Electrochemistry. Voltammetry. Cyclic and square wave voltammetric measurements were performed on compounds 1c, 1o, 2c, 2o, $\mathbf{R u}(\mathbf{2 c})$, and $\mathbf{O s}(\mathbf{2 c})$. The corresponding redox potentials are listed in Table 3 .

The cyclic voltammogram of $\mathbf{1 c}$ in THF at room temperature shows a reversible cathodic wave at $E_{1 / 2}=-1.85 \mathrm{~V}$ $\left(v=100 \mathrm{mV} \mathrm{s}^{-1}\right)$, which becomes electrochemically quasireversible at $210 \mathrm{~K}$ (see Figure 4). In the literature, a similar cyclic voltammogram was reported for 1c in DMF. ${ }^{65}$ No cathodic wave was reported for a spiropyran lacking the nitro substituent. The reduction of 1c must therefore be largely localized at the $\mathrm{NO}_{2}$ group.

(54) Mondal, J. A.; Ramakrishna, G.; Singh, A. K.; Ghosh, H. N.; Mariappan, M.; Maiya, B. G.; Mukherjee, T.; Palit, D. K. J. Phys. Chem. A 2004, 108, 7843-7852.

(55) Welter, S.; Salluce, N.; Belser, P.; Groeneveld, M.; De Cola, L. Coord. Chem. Rev. 2005, 249, 1360-1371.

(56) Schoonover, J. R.; Dattelbaum, D. M.; Malko, A.; Klimov, V. I.; Meyer, T. J.; Styers-Barnett, D. J.; Gannon, E. Z.; Granger, J. C.; Aldridge, W. S.; Papanikolas, J. M. J. Phys. Chem. A 2005, 109, 2472-2475.

(57) Macpherson, A. N.; Liddell, P. A.; Kuciauskas, D.; Tatman, D.; Gillbro, T.; Gust, D.; Moore, T. A.; Moore, A. L. J. Phys. Chem. B 2002, 106, 9424-9433.

(58) Hania, P. R.; Heijs, D. J.; Bowden, T.; Pugzlys, A.; van Esch, J.; Knoester, J.; Duppen, K. J. Phys. Chem. B 2004, 108, 71-81.

(59) Andersson, J.; Puntoriero, F.; Serroni, S.; Yartsev, A.; Pascher, T.; Polivka, T.; Campagna, S.; Sundstrom, V. Chem. Phys. Lett. 2004, 386, 336-341.

(60) Krysanov, S. A.; Alfimov, M. V. Chem. Phys. Lett. 1982, 91, 77-80.

(61) Kalisky, Y.; Orlowski, T. E.; Williams, D. J. J. Phys. Chem. 1983, 87, 5333-5338.

(62) Lenoble, C.; Becker, R. S. J. Phys. Chem. 1986, 90, 62-65.

(63) Celani, P.; Bernardi, F.; Olivucci, M.; Robb, M. A. J. Am. Chem. Soc. 1997, 119, 10815-10820.

(64) Holm, A. K.; Rini, M.; Nibbering, E. T. J.; Fidder, H. Chem. Phys. Lett. 2003, 376, 214-219.

(65) Zhi, J. F.; Baba, R.; Hashimoto, K.; Fujishima, A. Ber. Bunsen-Ges. Phys. Chem. 1995, 99, 32-39.
Curiously, in the preceding study ${ }^{65}$ no shift of the cathodic wave was observed upon irradiation of nitrospiropyran 1c both at room temperature and $231 \mathrm{~K}$. It was therefore concluded that the reduction (and thus the LUMO) of $\mathbf{1 0}$ was also localized at the nitro group and that the reduction potential was not affected by the photoinduced structural changes. Theoretical calculations have shown, however, that the LUMO of 10 is delocalized over a large part of the molecule and only a fraction of the added electron density in the corresponding radical anion resides on the nitro group. ${ }^{66}$ In our experiments in THF, the cyclic voltammetric scan at $210 \mathrm{~K}$ did show a new quasi-reversible cathodic wave upon photoconversion of 1c to 10, which was shifted less negatively by ca. $200 \mathrm{mV}$ compared to the reduction of $\mathbf{1 c}$ (see Figure 4). This wave is attributed to the reduction of 10. This assignment is also in agreement with results of spectroelectrochemical experiments (see below). The change is reversible: when 10 converts thermally to the closed form, the wave disappears again.

A single irreversible anodic wave is observed for $\mathbf{1 c}$ at $E_{\mathrm{p}, \mathrm{a}}=+0.68 \mathrm{~V}$ at room temperature and $+0.92 \mathrm{~V}$ at $210 \mathrm{~K}$. When $1 \mathrm{c}$ is converted to 10 at $210 \mathrm{~K}$, a new irreversible anodic wave appears at $E_{\mathrm{p}, \mathrm{a}}=+0.67 \mathrm{~V}$, while the original wave at $+0.92 \mathrm{~V}$ becomes gradually diminished (see Figure 4).

To ensure that the differences between our results and those reported in the literature ${ }^{65}$ are not due to a different behavior of $\mathbf{1 c} / \mathbf{1 0}$ in various solvents, we performed a control experiment in DMF. In this solvent, 10 could be generated by steady-state irradiation with UV light at a sufficiently high concentration even at room temperature to observe the appearance of a cathodic wave at $E_{\mathrm{p}, \mathrm{c}}=-1.38 \mathrm{~V}$. The shift of this wave compared to $\mathbf{1 c}$ in DMF (see Table 3 ) is similar to what was observed in THF at low temperature. The degree of conversion was not high enough for the corresponding anodic counterpeak or a new anodic wave for 10 to become resolved. The most likely explanation for the discrepancy between our results and the literature ${ }^{65}$ is that in the earlier study the degree of photoconversion achieved at room temperature and at $231 \mathrm{~K}$ was insufficient to observe the reduction wave for $\mathbf{1 0}$.

From the above observations, we can conclude that both the reduction and oxidation of $\mathbf{1 0}$ are thermodynamically more feasible compared to $1 \mathrm{c}$. The voltammetric data in THF reveal that the HOMO-LUMO gap of $10(2.62 \mathrm{eV})$ is smaller by $\sim 0.5 \mathrm{eV}$ compared to $\mathbf{1 c}(2.14 \mathrm{eV})$. Neglecting reorganization energies, the lowest-energy electronic transition is expected around $470 \mathrm{~nm}$ for $1 \mathrm{c}$ and $580 \mathrm{~nm}$ for $\mathbf{1 0}$. The value for 10 is in excellent agreement with the UV-vis absorption data (see Table 1), but the lowest-energy absorption band of $1 \mathrm{c}$ lies much higher $(344 \mathrm{~nm}, 3.60 \mathrm{eV})$ than predicted by the electrochemical data. Ab initio MO calculations have shown, however, that the $S_{0} \rightarrow S_{1}$ transition of 1c has zero oscillator strength, and therefore, it is not

(66) Sheng, Y. H.; Leszczynski, J. Collect. Czech. Chem. Commun. 2004, 69, 47-62. 
Table 3. Reduction and Oxidation Potentials for Compounds under Study and Reference Compounds ${ }^{a}$

\begin{tabular}{|c|c|c|c|c|c|c|c|c|c|}
\hline compound & solvent & $T / \mathrm{K}$ & $\begin{array}{l}E_{1 / 2} / \mathrm{V} \\
\mathrm{M}^{\mathrm{II} / \mathrm{III}} \\
\end{array}$ & $\begin{array}{c}E_{1 / 2} / \mathrm{V} \\
\text { SP-NO }_{2}{ }^{0 /+}\end{array}$ & $\begin{array}{c}E_{1 / 2} / \mathrm{V} \\
\text { SP-NO }_{2}{ }^{0 /-}\end{array}$ & $\begin{array}{c}E_{1 / 2} / \mathrm{V} \\
\left(\mathrm{bpy}^{0 /-}\right)_{\mathrm{I}}\end{array}$ & $\begin{array}{c}E_{1 / 2} / \mathrm{V} \\
\left(\mathrm{bpy}^{0 /-}\right)_{\text {II }}\end{array}$ & $\begin{array}{c}E_{1 / 2} / \mathrm{V} \\
\left(\mathrm{bpy}^{0 /-}\right)_{\mathrm{III}}\end{array}$ & $\begin{array}{l}\Delta E_{\mathrm{p}} / \mathrm{V} \\
\mathrm{Fc} / \mathrm{Fc}^{+}\end{array}$ \\
\hline$\left[\mathrm{Ru}(\mathrm{bpy})_{3}\right]^{2+b}$ & $\mathrm{MeCN}$ & 293 & +0.89 & & & -1.72 & -1.93 & -2.18 & \\
\hline$\left[\mathrm{Os}(\mathrm{bpy})_{3}\right]^{2+c}$ & DMF & 293 & +0.35 & & & -1.67 & -1.85 & -2.17 & \\
\hline \multirow[t]{3}{*}{ 1c } & $\mathrm{THF}$ & 293 & & $+0.68^{d}$ & $-1.85(0.17)$ & & & & 0.14 \\
\hline & $\mathrm{THF}$ & 210 & & $+0.92^{d}$ & $-1.64(0.74)$ & & & & 0.19 \\
\hline & DMF & 293 & & $+0.65^{d}$ & $-1.68(0.09)$ & & & & 0.08 \\
\hline 10 & $\mathrm{THF}$ & 210 & & $+0.67^{d}$ & $-1.47(0.21)$ & & & & 0.17 \\
\hline \multirow[t]{2}{*}{$2 c$} & $\mathrm{THF}$ & 293 & & $+0.71^{d}$ & $-1.81(0.12)^{e}$ & & & & 0.12 \\
\hline & THF & 210 & & $+0.83(0.27)$ & $-1.63(0.46)^{e}$ & & & & 0.14 \\
\hline 20 & $\mathrm{THF}$ & 210 & & $+0.66^{d}$ & $-1.32(0.22)^{f}$ & & & & 0.20 \\
\hline \multirow[t]{3}{*}{ Ru-2c } & $\mathrm{THF}$ & 293 & $g$ & $+0.80(0.10)$ & $g$ & $-1.80(0.09)$ & $-2.01(0.12)$ & $-2.34(0.12)$ & 0.08 \\
\hline & $\mathrm{THF}$ & 210 & $+0.90(0.08)$ & $+0.73(0.09)$ & $-1.67(0.08)$ & $-1.73(0.04)$ & $-1.89(0.06)$ & $-2.20(0.07)$ & 0.04 \\
\hline & DMF & 293 & $\mathrm{~g}$ & $+0.81(0.07)$ & $-1.63^{h}$ & $-1.75(0.07)$ & $-1.95(0.07)$ & $-2.21(0.07)$ & 0.08 \\
\hline \multirow[t]{3}{*}{ Os-2c } & $\mathrm{THF}$ & 293 & $+0.33(0.06)$ & $+0.77^{i}$ & $g$ & $-1.73(0.07)$ & $-1.93(0.15)$ & $-2.35(0.12)$ & 0.08 \\
\hline & $\mathrm{THF}$ & 210 & $+0.32(0.06)$ & $+0.81^{i}$ & $g$ & $-1.73(0.04)$ & $-1.90(0.05)$ & $-2.31(0.05)$ & 0.05 \\
\hline & DMF & 293 & $+0.36(0.08)$ & $g$ & $-1.60^{h}$ & $-1.67(0.07)$ & $-1.87(0.06)$ & $-2.22(0.09)$ & 0.08 \\
\hline
\end{tabular}

${ }^{a}$ Redox potentials $\left(\mathrm{V}\right.$ vs $\mathrm{Fc} / \mathrm{Fc}^{+}$) were determined from cyclic and Osteryoung square-wave voltammetric scans. $\Delta E_{\mathrm{p}}$ values $(\mathrm{cyclic}$ voltammetry) are given in brackets. Experimental conditions: Pt disk working microelectrode, $v=100 \mathrm{mV} \mathrm{s}^{-1}$ (cyclic voltammetry), $f=30 \mathrm{~Hz}$ (s-w voltammetry). ${ }^{b}$ Reference 68. ${ }^{c}$ References 69,70 , using $E_{1 / 2}\left(\mathrm{Fc} / \mathrm{Fc}^{+}\right)=+0.48 \mathrm{~V}$ vs SCE in DMF. ${ }^{d} E_{\mathrm{p}, \mathrm{a}} .{ }^{e}$ The second cathodic step $\left(E_{\mathrm{p}, \mathrm{c}}=-2.90 \mathrm{~V}\right.$ at room temperature and -2.83 $\mathrm{V}$ at $231 \mathrm{~K})$ is totally irreversible and is most likely not localized exclusively at the bpy moiety. ${ }^{f}$ The second, irreversible cathodic step is found at $E_{\mathrm{p}, \mathrm{c}}=$ $-2.28 \mathrm{~V}$, and is probably localized at the spiropyran moiety. ${ }^{g}$ Not observed. ${ }^{h} E_{\mathrm{p}, \mathrm{c} .}{ }^{i}$ Peak potentials from square-wave voltammograms.

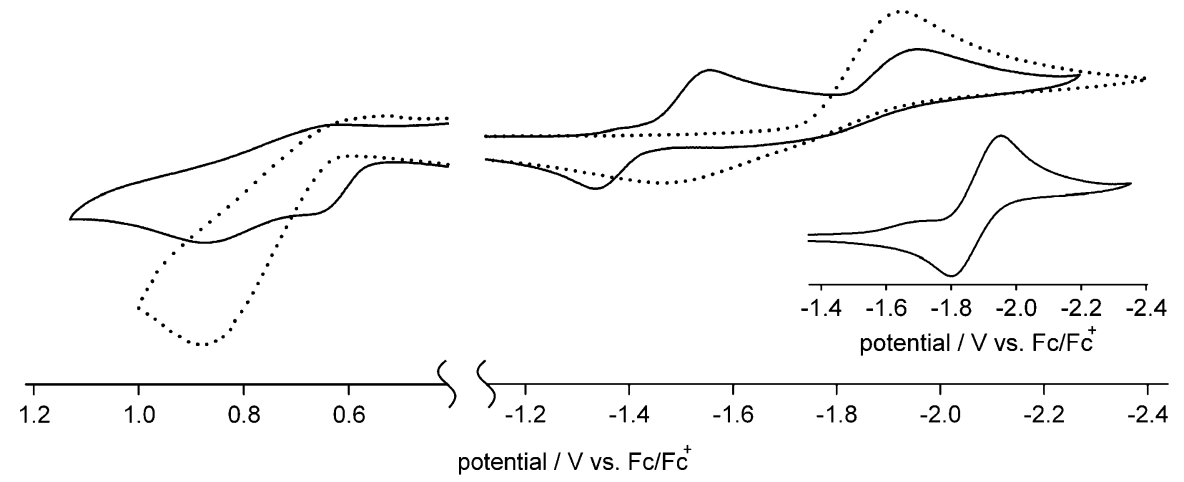

Figure 4. $1 \mathbf{1 c}(\cdots)$ and $\mathbf{1 c} / \mathbf{1 0}\left(-, 40 \%\right.$ photoconversion), scanned by cyclic voltammetry in THF solution at $210 \mathrm{~K}$. Scan rate $v=100 \mathrm{mV} \mathrm{s}{ }^{-1}$. Inset: $\mathbf{1 c}$ at $293 \mathrm{~K}$.

observable in the UV-vis spectrum. ${ }^{67}$ Its position was calculated at ca. $2.70 \mathrm{eV}$ for $\mathbf{1 c}$ in the gas phase. This value is in much better agreement with our experimental estimate. According to the calculations, the absorption band of $1 \mathbf{c}$ at $344 \mathrm{~nm}$ in fact corresponds to the symmetry-allowed $\mathrm{S}_{0} \rightarrow$ $\mathrm{S}_{3}$ transition.

Similar to $\mathbf{1 c}$, reduction of $\mathbf{2 c}$ is also reversible at room temperature and becomes electrochemically quasi-reversible at $210 \mathrm{~K}$. The assignment to the reduction of the nitro group is supported by the very close values of the reduction potentials (see Table 3). Upon conversion of $\mathbf{2 c}$ to $\mathbf{2 o}$ at 210 $\mathrm{K}$, shifts of the first anodic and cathodic waves are observed, similar to the differences in the potentials of $\mathbf{1 c}$ and $\mathbf{1 0}$.

For Ru-2c in THF at room temperature, three reversible cathodic waves can be distinguished at $E_{1 / 2}=-1.80,-2.01$, and $-2.34 \mathrm{~V}$, respectively. By analogy with the reduction of $\left[\mathrm{Ru}(\mathrm{bpy})_{3}\right]^{2+},{ }^{68}$ these three waves are assigned to the sequential reduction of the three bipyridine units at the ruthenium center. We do not observe a resolved wave for the reduction of the nitro group. At $210 \mathrm{~K}$, the three bipyridine reductions shift slightly to $E_{1 / 2}=-1.73,-1.89$,

(67) Cottone, G.; Noto, R.; La Manna, G.; Fornili, S. L. Chem. Phys. Lett. 2000, 319, 51-59.

(68) Sutin, N.; Creutz, C. Adv. Chem. Ser. 1978, 168, 1-27. and $-2.20 \mathrm{~V}$, respectively, and another cathodic wave becomes resolved at $E_{1 / 2}=-1.67 \mathrm{~V}$ (see Figure 5). This wave belongs to the reduction of the nitro group of the $\mathbf{2 c}$ moiety. This assignment has been confirmed by UV-vis spectroelectrochemistry (see below). The fact that the reduction of the nitro group and the first bipyridine reduction overlap, suggests that the electronic interaction between the metal-bipyridine and nitrospiropyran moieties in the ground state is very limited.

For Os-2c in THF, the cathodic wave pattern is similar to that of Ru-2c. At $210 \mathrm{~K}$, three reversible cathodic processes are observed at $-1.73,-1.90$, and $-2.31 \mathrm{~V}$. The reduction of the nitro group remains unresolved in this case. At room temperature, these cathodic waves broaden and shift slightly to $E_{1 / 2}=-1.73,-1.93$, and $-2.35 \mathrm{~V}$, respectively.

Because of the low ring-opening photoreaction quantum yields, it was experimentally not feasible to determine the redox potentials of Ru-2o and Os-2o. We can reasonably assume that the $\mathrm{Ru}$-bpy-based redox steps will not be much affected by the spiropyran ring-opening. This assumption is supported by the negligible shift of the lowest-energy ${ }^{1} \mathrm{MLCT}$ absorption in the UV-vis absorption spectra of the metal complexes upon conversion to the open form (see Figure 3 and Table 1). 


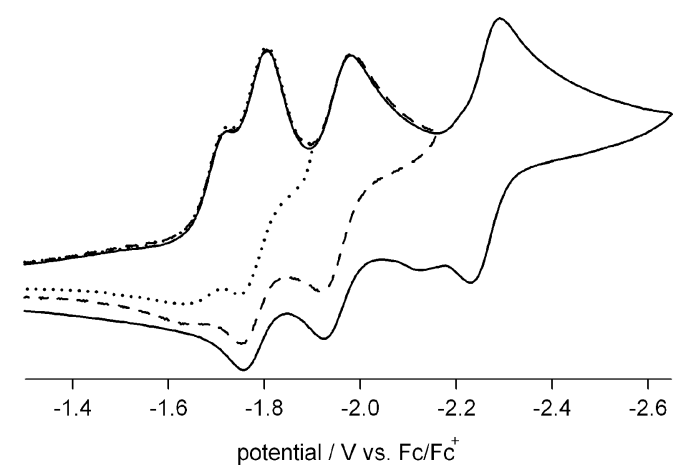

Figure 5. Cathodic region of Ru-2c, scanned by cyclic voltammetry in THF solution at $210 \mathrm{~K}$. Scan rate $v=100 \mathrm{mV} \mathrm{s}^{-1}$.

Spectroelectrochemistry. In the literature, UV-vis spectroelectrochemical experiments with $\mathbf{1 c}$ were performed in DMF at $231 \mathrm{~K}$. The one-electron-reduced species was identified by ${ }^{1} \mathrm{H}$ NMR spectroscopy as ring-closed species $1 \mathbf{c}^{\bullet-} .{ }^{71}$ A cyclic voltammogram recorded at a scan rate of $60 \mathrm{mV} \mathrm{s}^{-1}$ showed that the reduction of $\mathbf{1 c}$ to $1 \mathbf{c}^{\mathbf{0}^{-}}$was not a reversible process. Instead of the anodic counter peak, two new anodic waves appeared on the reverse voltammetric scan, the first one lying more than $1.5 \mathrm{~V}$ more positively than the original cathodic wave. ${ }^{71}$ From this potential shift, we conclude that the molecular structures of $\mathbf{1 c}$ and $\mathbf{1} \mathbf{c}^{\mathbf{-}}$ must differ in some way. The electrolytic oxidation of $\mathbf{1} \mathbf{c}^{--}$ was claimed to result directly in the formation of 10 that could be converted to $\mathbf{1 c}$ thermally or by irradiation with visible light. ${ }^{71}$ Smooth recovery of $1 \mathbf{c}^{\mathbf{0}^{-}}$was monitored by $\mathrm{UV}$ - vis spectroscopy when the electrode potential was stepped back to the cathodic wave of $\mathbf{1 c}$.

Our results in THF indicate that the smooth electrochemical interconversion between $1 \mathbf{c}^{\circ-}$ and $\mathbf{1 o}$ is an oversimplification. Gradual reduction of $\mathbf{1 c}$ at room temperature within an OTTLE cell, monitored by UV-vis spectroscopy, resulted in the appearance of the electronic absorption spectrum of $\mathbf{1 c}^{\mathbf{c}^{-}}$(see Figure 6a), in accordance with the literature. ${ }^{71}$ Also in THF, this process is not reversible on the time scale of the experiment, and the reverse oxidation takes place at a much higher electrode potential than the reduction of $\mathbf{1 c}$. The reverse thin-layer cyclic voltammogram displayed two distinct anodic waves, similar to the cyclic voltammogram in DMF reported in the literature. ${ }^{71}$ During the first anodic step, however, $\mathbf{1 c}^{\mathbf{0}}$ was oxidized to give an unassigned product B1 instead of parent 1c, or 10 expected on grounds of the reported anodic behavior. ${ }^{71}$ This process was characterized by decreasing intensity of the characteristic absorption band at $450 \mathrm{~nm}$ of the reduced $\mathrm{NO}_{2}{ }^{--}$chromophore in $1 \mathbf{c}^{\bullet-}$, accompanied by a gradual blue-shift of the absorption maximum (see Figure 6b). Several isosbestic points in the $\mathrm{UV}$ - vis spectra point to inherent stability of B1 that could be converted smoothly back to $1 \mathbf{c}^{--}$by reduction close to the cathodic wave of 1c. During the second reverse anodic step (oxidation of B1), an absorption band grew around 580 $\mathrm{nm}$, which revealed the formation of $\mathbf{1 0}$ (see Figure 6c). This

(69) Saji, T.; Aoyagui, S. J. Electroanal. Chem. 1975, 58, 401-410.

(70) Saji, T.; Aoyagui, S. J. Electroanal. Chem. 1975, 60, 1-10.

(71) Zhi, J. F.; Baba, R.; Hashimoto, K.; Fujishima, A. J. Photochem. Photobiol. A: Chem. 1995, 92, 91-97.
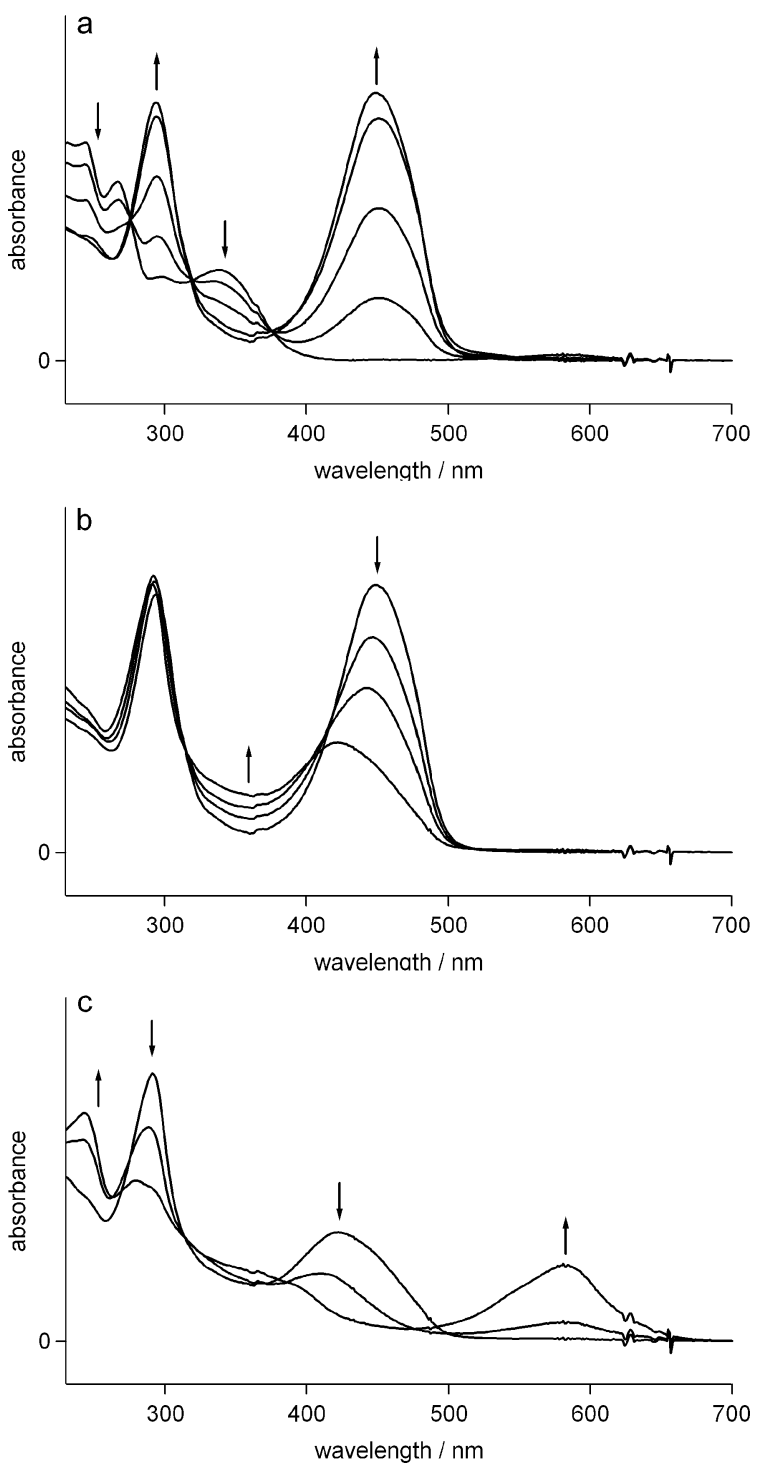

Figure 6. UV-vis spectral changes in THF solution at $293 \mathrm{~K}$ accompanying (a) reduction of $\mathbf{1 c}$ to $1 \mathbf{c}^{\bullet-}$, (b) oxidation of $\mathbf{1 c}^{\mathbf{c}^{-}}$to yet unassigned species B1, and (c) oxidation of B1 producing 1o. Electrolysis within an OTTLE cell.

band disappeared in time due to thermal conversion of $\mathbf{1 0}$ to $\mathbf{1 c}$, and the starting spectrum of $\mathbf{1 c}$ was recovered.

As two well separated anodic steps are required to oxidize one-electron-reduced $1 \mathbf{c}^{--}$to neutral 1o, both oxidations must formally consume 0.5 electron. We therefore ascribe B1 tentatively a "dimeric" structure, existing of one neutral and one singly reduced nitrospiropyran molecule, to account for the fact that clear electrochemical reduction and oxidation of this species is needed to produce the known "monomeric" structures $1 \mathbf{c}^{\mathbf{*}}$ and $\mathbf{1 0}$, respectively. A detailed study of this intriguing redox behavior and structural assignment of B1 was, however, beyond the scope of this investigation.

To ensure that the differences between our spectroelectrochemical data and those in the literature report ${ }^{71}$ are not caused by a different redox behavior of $\mathbf{1 c}$ in various solvents, we also studied 1c in DMF at room temperature. The cyclic voltammogram we recorded of $1 \mathrm{c}$ at $100 \mathrm{mV} \mathrm{s}^{-1}$ resembles closely that reported in the literature. The irreversible cathodic wave of $\mathbf{1} \mathbf{c}$ to $1 \mathbf{c}^{\mathbf{0}^{-}}$was found at $E_{\mathrm{p}, \mathrm{c}}=-1.72$ 


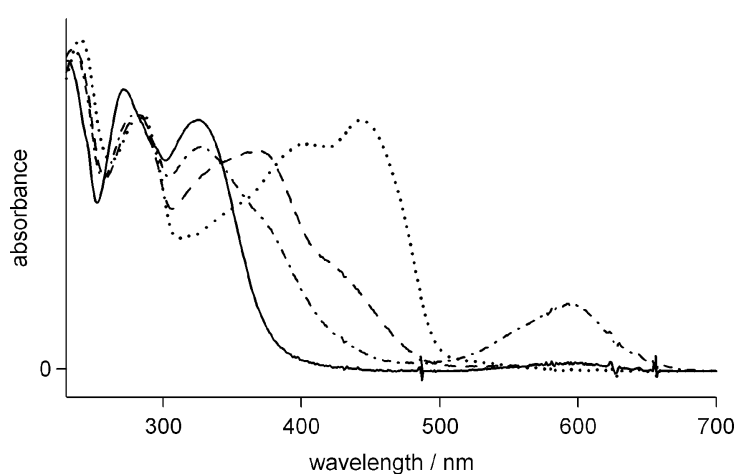

Figure 7. UV-vis spectra in THF solution at $293 \mathrm{~K}$ of neutral $\mathbf{2 c}(-)$, one-electron-reduced $2 \mathbf{c}^{--}(\cdots)$, unassigned species B2 produced by reverse oxidation of $\mathbf{2} \mathbf{c}^{-}(---)$and a mixture of $\mathbf{2 c / 2 o}$ formed in the course of the oxidation of B2 $(-\cdot-)$. Electrolysis within an OTTLE cell.

$\mathrm{V}$ vs $\mathrm{Fc} / \mathrm{Fc}^{+}$. A small anodic counter peak persisted down to a scan rate of $50 \mathrm{mV} \mathrm{s}^{-1}$. On the positive potential sweep, two irreversible anodic waves were observed at -0.26 and $0.07 \mathrm{~V}$, respectively.

In the course of spectroelectrochemical experiments with 10 in DMF at room temperature, a qualitatively identical picture was observed as in THF. However, 1o, formed by the stepwise oxidation of $\mathbf{1} \mathbf{c}^{--}$and $\mathrm{B} 1$, converts thermally to $1 \mathrm{c}$ in DMF at a much lower rate than in THF. A similar solvent dependence was observed for photogenerated 10 (see above). This slow kinetics in DMF allowed us to study the redox behavior of $\mathbf{1 0}$ at room temperature also. In agreement with the conventional cyclic voltammogram of the photogenerated compound, 10 formed by the electrolytic cycle within the thin-layer spectroelectrochemical cell is reduced at a less negative electrode potential than 1c. During the reduction of 1o, the characteristic low-lying band at $580 \mathrm{~nm}$ disappears and the resulting $\mathrm{UV}-$ vis spectrum strongly resembles that of product B1. As further evidenced by the thin-layer cyclic voltammogram and the UV-vis spectra, this species can be subsequently reduced to give $\mathbf{1 c}^{--}$or oxidized directly to 10 , in accordance with the separate redox couples $\mathbf{1 \mathbf { c } ^ { - }} / \mathrm{B} 1$ and B1/1o observed in THF (see above).

Electrochemical reduction of $\mathbf{2 c}$ in THF results in UVvis spectral changes similar to those observed upon reduction of 1c (see Figure 7), confirming its localization on the nitrospiropyran moiety and not on the $2,2^{\prime}$-bipyridyl substituent. ${ }^{72}$ Identical to $\mathbf{1 c}$, the reduction of $\mathbf{2 c}$ is not a reversible process on the spectroelectrochemistry time scale, and oxidation of $\mathbf{2 \mathbf { c } ^ { - - }}$ to form $\mathbf{2 0}$ occurs in two separate anodic steps, involving an unassigned redox intermediate B2. This species is assumed to be structurally similar to intermediate B1 involved in the redox cycle of 1c/10.

Electrochemical reduction of Ru-2c in THF within the OTTLE cell resulted in diminished intensity of all absorption bands in the UV-vis spectrum, most likely as a result of poor solubility of the reduced product in this solvent. Therefore, the UV-vis spectroelectrochemical experiment with Ru-2c was performed in DMF. In the latter solvent, four well-separated cathodic steps could be distinguished in

(72) Krejèík, M.; Vlèek, A. A. J. Electroanal. Chem. 1991, 313, 243257.

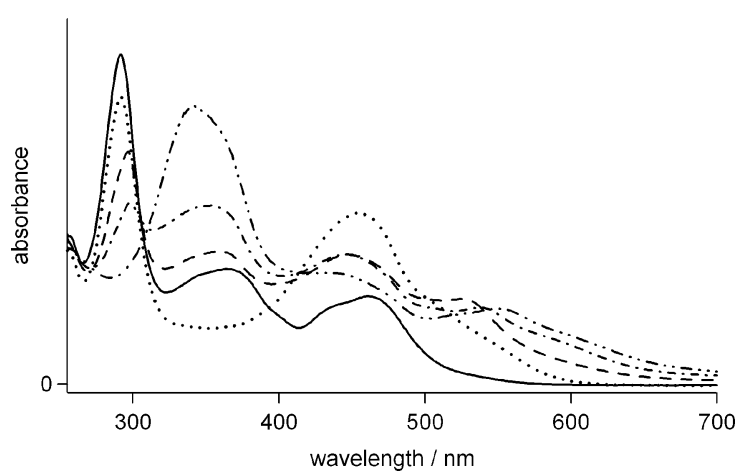

Figure 8. UV-vis spectra in DMF solution at $293 \mathrm{~K}$ of Ru-2c (-), and the corresponding one-electron-reduced $(\cdots)$, two-electron-reduced $(---)$, three-electron-reduced $(-\cdot-)$ and four-electron-reduced $(-\cdot-)$ species. Electrolysis within an OTTLE cell.

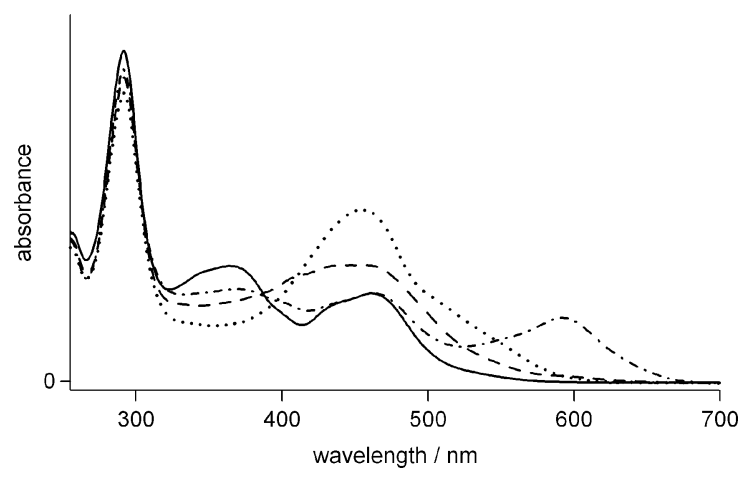

Figure 9. UV-vis spectra in DMF solution at $293 \mathrm{~K}$ of Ru-2c (-), the corresponding one-electron-reduced species $\mathbf{R u}-\mathbf{2}^{\mathbf{c}^{-}}(\cdots)$, unassigned species B3 $(---)$ produced by the reverse oxidation of $\mathbf{R u}-\mathbf{2} \mathbf{c}^{--}$, and a mixture of Ru-2c/Ru-2o formed in the course of the oxidation of B3 $(-\cdot-)$. Electrolysis within an OTTLE cell.

the thin-layer cyclic voltammogram, in line with the conventional cyclic voltammetric scan in THF at $210 \mathrm{~K}$ (see Figure 5) and in DMF (see Table 3). The UV-vis spectral changes accompanying the conversion of Ru-2c to oneelectron-reduced species $\mathbf{R u}-\mathbf{2} \mathbf{c}^{\bullet-}$ (see Figure 8) resemble in main features those registered for $\mathbf{2} \mathbf{c}$ and $\mathbf{2} \mathbf{c}^{-\boldsymbol{*}}$ (see Figure 7). The subsequent three cathodic steps result in UV-vis spectral changes similar to those observed for $\left[\mathrm{Ru}(\mathrm{bpy})_{3}\right]^{2+}{ }^{73}$ Importantly, the sharp $\pi \pi^{*}$ (IL $\mathrm{ILpy}_{\text {by }}$ band at $285 \mathrm{~nm}$ progressively completely disappeared as the result of the reduction of the bpy ligands in Ru-2c at the second to fourth cathodic waves. These waves are fully reversible on the spectroelectrochemical time scale of minutes, differently from the initial reduction. Based upon these results, the first cathodic wave is assigned to the reduction of the nitrospiropyran moiety, followed by three reductions of the bpy ligands. The oxidation of $\mathbf{R u}-\mathbf{2} \mathbf{c}^{\mathbf{}}-$ at the scan reversal initiated directly beyond the first cathodic wave occurred again in two steps, identical to the anodic behavior of $\mathbf{2 \mathbf { c } ^ { - - }}$ and $\mathbf{1} \mathbf{c}^{\mathbf{}}$. The first oxidation process resulted in the formation of yet unassigned species B3 that converted (at least partially) to Ru-2o in the second anodic step (see Figure 9). This complex is thermally unstable in DMF and transforms quickly to $\mathbf{R u - 2 c}$, which prevented the study of its redox behavior at room temperature.

(73) Heath, G. A.; Yellowlees, L. J.; Braterman, P. S. Chem. Commun. 1981, 287-289. 
Table 4. Emission Maxima $\left(\lambda_{\max }\right)$, Lifetimes $(\tau)$, and Quantum Yields $\left(\varphi_{\mathrm{em}}\right)$ of the Investigated Photochromic Compounds in Their Open and Closed Forms $^{a}$

\begin{tabular}{|c|c|c|c|c|c|}
\hline compound & $\lambda_{\max } / \mathrm{nm}$ & $\tau / \mathrm{ns}$ & $\varphi_{334}$ & $\varphi_{450}$ & $\varphi_{600}$ \\
\hline 10 & 651 & $\begin{array}{l}\tau_{1}=0.057(0.74) \\
\tau_{2}=0.163(0.26)\end{array}$ & $4.8 \times 10^{-2}$ & $b$ & $4.8 \times 10^{-2}$ \\
\hline 20 & 660 & $\begin{array}{l}\tau_{1}=0.070(0.75) \\
\tau_{2}=0.166(0.25)\end{array}$ & $5.8 \times 10^{-2}$ & $b$ & $5.7 \times 10^{-2}$ \\
\hline $\mathrm{Ru}-2 \mathrm{c}$ & 634 & $\begin{array}{l}218 \text { (aer) } \\
973 \text { (deaer) }\end{array}$ & $\begin{array}{l}1.8 \times 10^{-2}(\text { aer }) \\
6.9 \times 10^{-2}(\text { deaer })\end{array}$ & $\begin{array}{l}1.6 \times 10^{-2}(\text { aer }) \\
6.9 \times 10^{-2}(\text { deaer })\end{array}$ & $b$ \\
\hline $\mathrm{Ru}-2 \mathrm{o}$ & 655 & $\begin{array}{l}\tau_{1}=0.077(0.89)^{c} \\
\tau_{2}=0.221(0.11)\end{array}$ & $9.4 \times 10^{-3 d}$ & $6.3 \times 10^{-3 d}$ & $4.7 \times 10^{-2}$ \\
\hline Os-2c & 765 & $\begin{array}{l}29 \text { (aer) } \\
34 \text { (deaer) }\end{array}$ & $2.2 \times 10^{-3}$ & $2.5 \times 10^{-3}$ & $2.4 \times 10^{-3}$ \\
\hline Os-2o & 765 & $\begin{array}{l}29 \text { (aer) }^{e} \\
34 \text { (deaer) }\end{array}$ & $2.2 \times 10^{-3 e}$ & $2.5 \times 10^{-3 e}$ & $2.4 \times 10^{-3 e}$ \\
\hline
\end{tabular}

${ }^{a}$ Experimental conditions: in THF, at $223 \mathrm{~K} .{ }^{b}$ Does not absorb at this wavelength. ${ }^{c}$ Data refer only to the analysis of the short-lived component in the emission decay trace of a mixture of $\mathbf{R u - 2 c / R u - 2 o}$. The long component was assigned to Ru-2c. ${ }^{d}$ Value extrapolated from the spectrum for $\mathbf{R u - 2 c / R u - 2 0}$

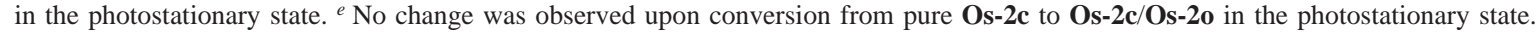

The UV-vis spectroelectrochemical experiment performed with Os-2c in DMF revealed the same redox behavior as described for Ru-2c (see Table 3). The UV-vis spectra of the different redox products are depicted in Figure S1 (Supporting Information). On the basis of these results, we can conclude that the modification of $\mathbf{2} \mathbf{c}$ with the attached

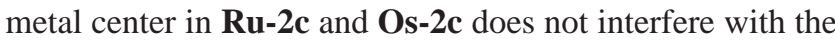
reduction/reoxidation pathway to form the open merocyanine structure. These metalated nitrospiropyran compounds undergo efficient electrochemically induced conversion to the merocyanine open form, in contrast with the low reaction quantum yields of the photochemical transformation.

Finally, it should be noted that the electrochemical formation of the open-form compounds at room temperature is not a clean process. For all the investigated nitrospiropyran compounds, repeated reduction/reoxidation cycles result in a significant irreversible change in the shape of the $\mathrm{IL}_{\mathrm{SP}}$ absorption band, indicative of spiropyran decomposition.

Luminescence Properties. Emission maxima, quantum yields, and lifetimes at $223 \mathrm{~K}$ in THF are reported for all investigated compounds in Table 4. For the closed forms of the investigated compounds, there is no significant difference in emission characteristics going from room temperature to $223 \mathrm{~K}$. We could not confirm this behavior for the corresponding open forms, as they are thermally unstable at room temperature.

Both $\mathbf{1 c}$ and $\mathbf{2 c}$ are nonemissive. After conversion to 10 and 2o, respectively, emissions appears with a maximum at $651 \mathrm{~nm}$ for $1 \mathrm{o}$ and $660 \mathrm{~nm}$ for $2 \mathrm{o}$ (see Figure 10). This result is in agreement with characteristic emission properties of open-form spiropyrans. ${ }^{20,74,75}$

Differently from 1c and 2c, which do not emit, Ru-2c has en emission at $634 \mathrm{~nm}$ (see Figure 11). The shape and intensity of the emission band, as well as the emission lifetime (see Table 4), point to its origin in a Ru-to-bpy ${ }^{3}$ MLCT excited state. ${ }^{39}$ Neither the emission quantum yield nor the shape of the emission band depends on the excitation wavelength. This means that population of the $\mathrm{IL}_{\mathrm{SP}}$ state of

(74) Balny, C.; Douzou, P.; Bercovici, T.; Fischer, E. Mol. Photochem. 1969, 1, 225-233.

(75) Kholmanskii, A. S.; Dyumaev, K. M. Russ. Chem. Rev. 1987, 56, 241-266.

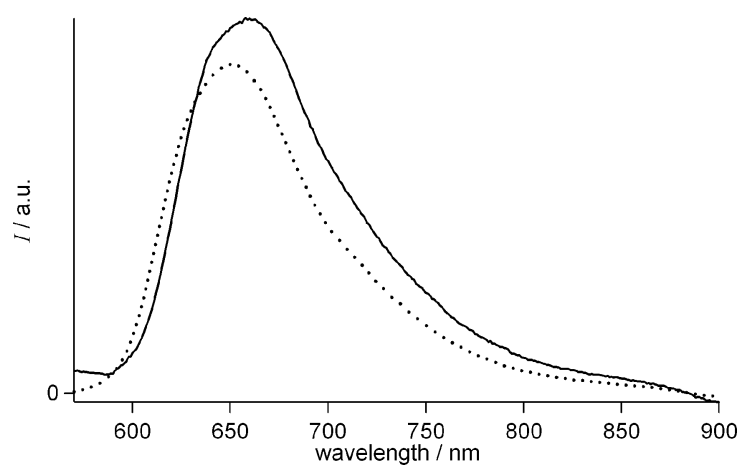

Figure 10. Emission spectra in THF solutions at $223 \mathrm{~K}$ of $\mathbf{1 0}(\cdots)$ and 20 $(-)$. Excitation wavelength $\lambda_{\mathrm{exc}}=334 \mathrm{~nm}$.

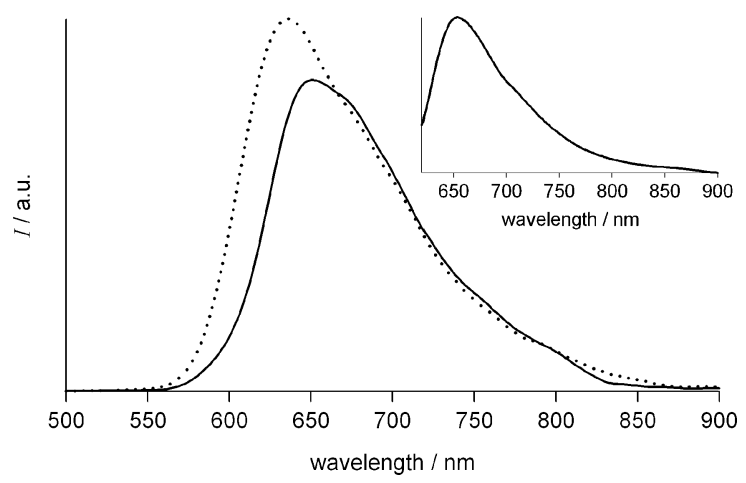

Figure 11. Emission spectra in air-equilibrated THF solution at $223 \mathrm{~K}$ of Ru-2c $(\cdots)$, and Ru-2c/Ru-2o in the photostationary state (-). Excitation wavelength $\lambda_{\text {exc }}=450 \mathrm{~nm}$. Inset: emission spectrum in air-equilibrated THF solution at $223 \mathrm{~K}$ of Ru-2o. Excitation wavelength $\lambda_{\mathrm{exc}}=600 \mathrm{~nm}$.

Ru-2c is followed by energy transfer to the lower-lying MLCT excited states. The efficiency of this process must be close to unity because, if a significant amount of energy was lost by internal conversion to the ground state or by population of other trapping excited states not communicating with the MLCT states, this would result in a lower emission quantum yield for the $\mathrm{IL}_{\mathrm{SP}}$ excitation compared to the MLCT excitation. The experimental result is consistent with the nanosecond transient absorption data (see below) and with the fact that the photochemical ring-opening quantum yield for excitation into the spiropyran-centered bands is more than 10 times lower for $\mathbf{R u - 2 c}$ compared to $\mathbf{2 c}$. 


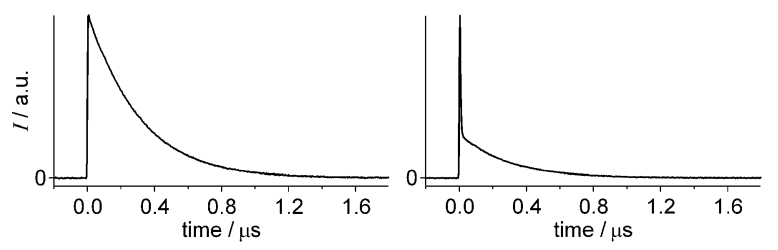

Figure 12. Emission decay traces of Ru-2c (left) and Ru-2c/Ru-2o (right) in air-equilibrated THF solution at $223 \mathrm{~K}$. Excitation wavelength $\lambda_{\mathrm{exc}}=$ $450 \mathrm{~nm}$.

Upon conversion of $\mathbf{R u - 2 c}$ to $\mathbf{R u - 2 o}$, the emission triggered by excitation at $450 \mathrm{~nm}$ gradually shifts to longer wavelengths, while its intensity slightly decreases (see Figure 11). This shift can be explained by assuming that in $\mathbf{R u - 2 0}$ the ${ }^{1} \mathrm{IL}_{\mathrm{SP}}$ excited states lie lower in energy than the ${ }^{3} \mathrm{MLCT}$ levels. Irradiation into the ${ }^{1}$ MLCT band at $450 \mathrm{~nm}$ induces energy transfer to the ${ }^{1} \mathrm{IL}_{\mathrm{SP}}$ excited states for Ru-2o. From the emission measurements on $\mathbf{1 0}$ and 2o, we know that the open nitrospiropyrans show fluorescence around $660 \mathrm{~nm}$, i.e., at a slightly lower energy than the ruthenium ${ }^{3} \mathrm{MLCT}$ emission. When a partially converted sample of $\mathbf{R u - 2 c}$ is irradiated with $600 \mathrm{~nm}$ light, thereby selectively exciting the open form Ru-2o and directly populating the lowest $\mathrm{IL}_{S P}$ excited states below the MLCT states, indeed an emission is observed with a maximum at $655 \mathrm{~nm}$ (see Figure 11, inset).

Clear evidence for this change in the luminescence nature can be obtained readily by monitoring the emission lifetimes upon conversion of $\mathbf{R u - 2 c}$ to $\mathbf{R u - 2 0}$. The $\left[\mathrm{Ru}(\mathrm{bpy})_{3}\right]^{2+}{ }_{-}$ type ${ }^{3}$ MLCT emission typically lives hundreds of nanoseconds in aerated conditions, ${ }^{39}$ while the open forms of spiropyrans have emission lifetimes in the sub-nanosecond time domain. ${ }^{11}$

If we monitor the emission of Ru-2c in the nanosecond time domain, a monoexponential decay is observed, with $\tau$ $=218 \mathrm{~ns}$ in air-equilibrated and $\tau=973 \mathrm{~ns}$ in deaerated THF. Converting Ru-2c to Ru-2o, a short-lived component appears in the emission decay profile. The relative weight of the latter component increases with increasing conversion (see Figure 12).

A single photon-counting (SPC) study with picosecond time resolution has revealed that the emission lifetime of the short component is very similar to those of $\mathbf{1 0}$ and $\mathbf{2 0}$ (see Table 4). Hence, we can conclude that the emission of Ru-2o originates from the lowest ${ }^{1} \mathrm{IL}_{\mathrm{SP}}$ state. The biexponential nature of the emission decay for 1o, 2o, and Ru-2o (see Table 4) can be understood by considering the open form of the spiropyran species to exist as a mixture of conformers having different emission lifetimes. ${ }^{11}$

Irradiation of a mixture of Ru-2c and Ru-2o with $600 \mathrm{~nm}$ light, thereby selectively exciting directly into the lowest excited state of Ru-2o, which has ${ }^{1} \mathrm{IL}_{\mathrm{SP}}$ character, yields an emission with a quantum yield of $4.7 \times 10^{-2}$. This value is very similar to the quantum yields of $\mathbf{1 0}$ and $\mathbf{2 0}$ (see Table 4). Extrapolation of the emission data for a mixture of $\mathbf{R u - 2 \mathbf { c } \text { and }}$ Ru-2o yields an emission quantum yield for Ru-2o upon excitation with $450 \mathrm{~nm}$ light of only $6.3 \times 10^{-3}$, which is significantly lower compared to the value determined for 600 nm excitation.
The dependence of the emission quantum yield of Ru-2o on the excitation wavelength can be understood by considering open-form spiropyrans as strictly singlet emitters. ${ }^{20,75} \mathrm{By}$ exciting Ru-2o with $600 \mathrm{~nm}$ light, the emissive ${ }^{1} \mathrm{IL}_{\mathrm{SP}}$ level is populated directly. Excitation with $450 \mathrm{~nm}$ light, however, leads to population of the Ru-to-bpy ${ }^{1} \mathrm{MLCT}$ state, followed by fast ISC to the ${ }^{3} \mathrm{MLCT}$ state. Consequently, excitation energy must be transferred from this state to the lower-lying emissive ${ }^{1} \mathrm{IL}_{S P}$ level. This can occur by means of a Förster energy transfer mechanism, for which conservation of spin is not required. The ${ }^{3} \mathrm{MLCT}$ state of the $\left[\mathrm{Ru}(\mathrm{bpy})_{3}\right]^{2+}$ complex is not a pure triplet, however, but has been estimated to contain up to $10 \%$ singlet character, as a result of spinorbit coupling. ${ }^{76,77}$ It has been shown that, because of the spin-orbit coupling, energy transfer from the ${ }^{3}$ MLCT state of $\left[\mathrm{Ru}(\mathrm{bpy})_{3}\right]^{2+}$ to a singlet excited state of an organic energy acceptor is also possible by means of a Dexter energy transfer mechanism, for which the spin conservation rules apply. ${ }^{78}$ We can suggest that due to the coupling between the donor and acceptor units and the expected orbital overlap the most likely mechanism is the Dexter one. Only part of the excitation energy will be transferred to the ${ }^{1} \mathrm{IL}_{\mathrm{SP}}$ level, however, while part of it flows from the ${ }^{3} \mathrm{MLCT}$ directly to the nonemissive ${ }^{3} \mathrm{IL}_{\mathrm{SP}}$ levels. Therefore, the emission quantum yield upon direct ${ }^{1} \mathrm{IL}_{\mathrm{SP}}$ excitation of $\mathbf{R u - 2 0}$ is higher than the "sensitized" quantum yield.

Alternatively, energy transfer may occur directly from the ${ }^{1}$ MLCT to the ${ }^{1} \mathrm{IL}_{\mathrm{SP}}$ levels, in competition with ISC. Recently, it has been shown that singlet-state energy transfer from a polypyridine ruthenium center can compete with ISC, provided the energy-donor and -acceptor are close enough to each other. ${ }^{59}$ As in $\mathbf{R u - 2 o}$, the energy donor and acceptor are very closely coupled, also in our case, part of the excitation energy may be transferred from the ${ }^{1}$ MLCT to the emitting ${ }^{1} \mathrm{IL}_{\mathrm{SP}}$ states directly. For a $\left[\mathrm{Ru}(\mathrm{bpy})_{3}\right]^{2+}$-type system, ISC has been determined to be an extremely fast process, however, occurring with a half-life of 100 fs or less. ${ }^{79,80}$ This means energy transfer should occur at a unlikely high rate in order to achieve a population of the ${ }^{1} \mathrm{IL}_{\mathrm{SP}}$ sufficient to account for the observed emission quantum yield. Therefore, we do not believe that this mechanism plays an important role for our system.

Complex Os-2c emits at $765 \mathrm{~nm}$, with a lifetime of $29 \mathrm{~ns}$ in air-equilibrated THF and $34 \mathrm{~ns}$ in deaerated THF. The emission clearly originates from an Os-to-bpy ${ }^{3} \mathrm{MLCT}$ state. When converted to Os-2o, there is no change in the emission characteristics (spectral shape, position, lifetime, intensity) upon excitation at $450 \mathrm{~nm}$. Also when exciting with $600 \mathrm{~nm}$ light, we only observe emission from the osmium center, regardless of the degree of conversion. This indicates that in Os-2o energy must be transferred from the $\mathrm{IL}_{\mathrm{SP}}$ levels to

(76) Kober, E. M.; Meyer, T. J. Inorg. Chem. 1982, 21, 3967-3977.

(77) Kober, E. M.; Meyer, T. J. Inorg. Chem. 1984, 23, 3877-3886.

(78) Mandal, K.; Pearson, T. D. L.; Krug, W. P.; Demas, J. N. J. Am. Chem. Soc. 1983, 105, 701-707.

(79) Damrauer, N. H.; Cerullo, G.; Yeh, A.; Boussie, T. R.; Shank, C. V.; McCusker, J. K. Science 1997, 275, 54-57.

(80) Bhasikuttan, A. C.; Suzuki, M.; Nakashima, S.; Okada, T. J. Am. Chem. Soc. 2002, 124, 8398-8405. 


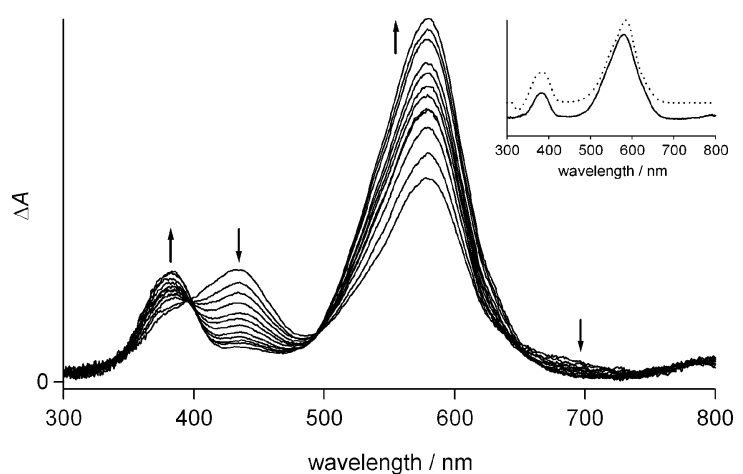

Figure 13. Transient absorption difference spectrum of $1 \mathbf{c}$ in airequilibrated THF at $293 \mathrm{~K}$, with a step size of $30 \mathrm{~ns}$ between frames. Excitation wavelength $\lambda_{\mathrm{exc}}=334 \mathrm{~nm}$. Inset: The final frame of the transient absorption spectrum ( - ) and the steady-state difference spectrum between 10 and $1 \mathrm{c}(\cdots)$.

the lowest emitting ${ }^{3}$ MLCT state, which has been estimated to contain up to $30 \%$ singlet character. ${ }^{76,77}$ From these results, we can conclude that, in contrast to Ru-2o, the lowest ${ }^{3} \mathrm{MLCT}$ excited state of $\mathbf{O s - 2 0}$ lies below the lowest ${ }^{3} \mathrm{IL}_{\mathrm{SP}}$ level.

Nanosecond Transient Absorption Spectroscopy. Nanosecond transient absorption spectroscopic studies have been performed in order to gain more insight in the excited-state processes. Reference compound 1c excited at $334 \mathrm{~nm}$ initially displays two absorption bands at 435 and $579 \mathrm{~nm}$ (see Figure 13). Under aerated conditions, the $435 \mathrm{~nm}$ band decays and the $579 \mathrm{~nm}$ band grows, both with lifetime $\tau=230 \mathrm{~ns}$. Also, a new band arises at $381 \mathrm{~nm}$ with $\tau=190 \mathrm{~ns}$. The 381 and $579 \mathrm{~nm}$ bands, once they reach their maximum intensity, do not decay on the time scale of the experiment. Within the fitting error, the three lifetime values are assigned to the same process. The temporal development in the spectrum is therefore attributed to the decay of an excited-state species and the formation of a photoproduct.

It is known that irradiation of $\mathbf{1 c}$ results in the appearance of two transient absorption bands in the nanosecond time domain, one around $430 \mathrm{~nm}$, the other around $570 \mathrm{~nm}$; the exact maxima of these bands depending on the solvent used. ${ }^{45,62,81}$ They decay with the same rate and have been assigned to a triplet excited state where the spiropyran ring is already open. ${ }^{45,62}$ Our observations in THF comply with this description.

The last frame of the transient absorption spectrum is virtually identical to the ground-state difference spectrum between 10 and 1c (see Figure 13, inset). Therefore, the absorption bands in this frame can be assigned to 10 in the ground state. Since the $579 \mathrm{~nm}$ absorption band of the precursor triplet state overlaps strongly with that of the ground-state species, the rise in time observed for this band is the result of the decay of the triplet excited state and the simultaneous growth of the more intense ground-state absorption.

The nanosecond transient absorption spectrum generated by $334 \mathrm{~nm}$ irradiation of $\mathbf{2 c}$ is very similar to those of $\mathbf{1 0}$

(81) Ernsting, N. P.; Arthenengeland, T. J. Phys. Chem. 1991, 95, 55025509.

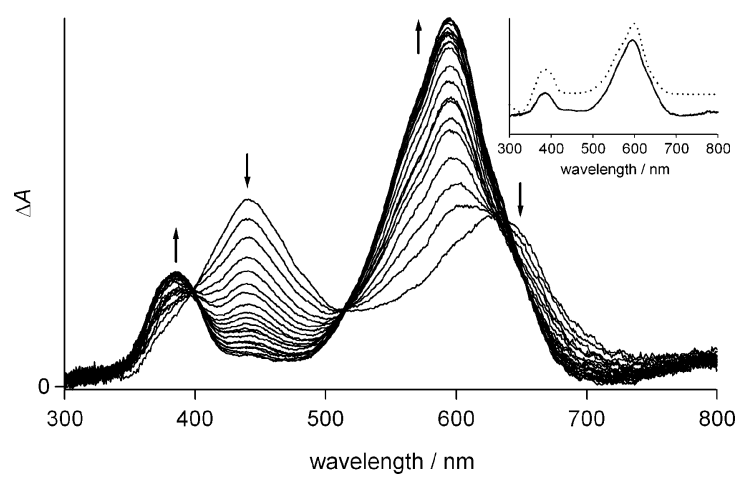

Figure 14. Transient absorption difference spectrum of $\mathbf{2 c}$ in airequilibrated THF at $293 \mathrm{~K}$, with a step size of $30 \mathrm{~ns}$ between frames. Excitation wavelength $\lambda_{\mathrm{exc}}=334 \mathrm{~nm}$. Inset: The final frame of the transient absorption spectrum ( - ) and the steady-state difference spectrum between 20 and $2 \mathrm{c}(\cdots)$.

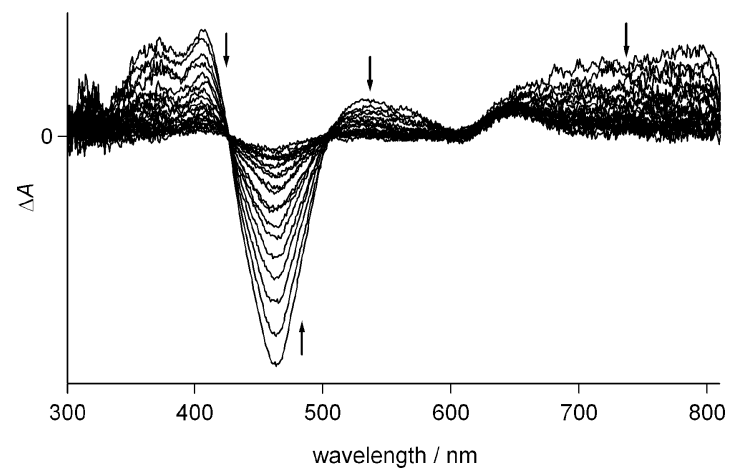

Figure 15. Transient absorption difference spectra of Ru-2c in airequilibrated THF at $293 \mathrm{~K}$, with a step size of $30 \mathrm{~ns}$ between frames. Excitation wavelength $\lambda_{\mathrm{exc}}=450 \mathrm{~nm}$.

(see Figure 14). Two absorption bands appear directly after excitation at 440 and $630 \mathrm{~nm}$. The one at $440 \mathrm{~nm}$ decays with a lifetime of $210 \mathrm{~ns}$ under aerated conditions. The decay of the band at $630 \mathrm{~nm}$ is similar, but the lifetime could not be determined precisely due to a strong overlap with a new band growing at $594 \mathrm{~nm}(\tau=210 \mathrm{~ns})$. In analogy to 1o, the 440 and $630 \mathrm{~nm}$ absorption bands are ascribed to an openring species in a triplet excited state. Upon decay of this triplet excited state, 20 in the ground state is formed, characterized by absorption bands at 385 and $594 \mathrm{~nm}$.

Figure 15 shows the transient absorption spectrum of Ru2c obtained at $\lambda_{\text {exc }}=450 \mathrm{~nm}$. The transient triplet-state species observed for 1c and $\mathbf{2 c}$ was not found. Instead, the spectrum shows the bleach of the MLCT absorption band at $464 \mathrm{~nm}$, accompanied by an absorption band below $425 \mathrm{~nm}$ and unresolved absorption in nearly the whole region above $500 \mathrm{~nm}$, with a break between 600 and $650 \mathrm{~nm}$. This pattern is characteristic of a ruthenium-to-bpy ${ }^{3} \mathrm{MLCT}$ excited state. ${ }^{82}$ The excited-state species decays to the ground state of Ru1c monoexponentially, with lifetimes of 200 and $960 \mathrm{~ns}$ in the presence and absence of oxygen, respectively. These values are in excellent agreement with the excited-state lifetimes determined from the emission measurements, again supporting the ${ }^{3}$ MLCT nature of the Ru-2c luminescence. The spectral shape of the transient absorption spectrum does not change during the decay. After the decay of the excited-

(82) Miedlar, K.; Das, P. K. J. Am. Chem. Soc. 1982, 104, 7462-7469. 
Scheme 4. Simplified Energetic Schemes for (a) Ru-2c and (b) Ru-2o
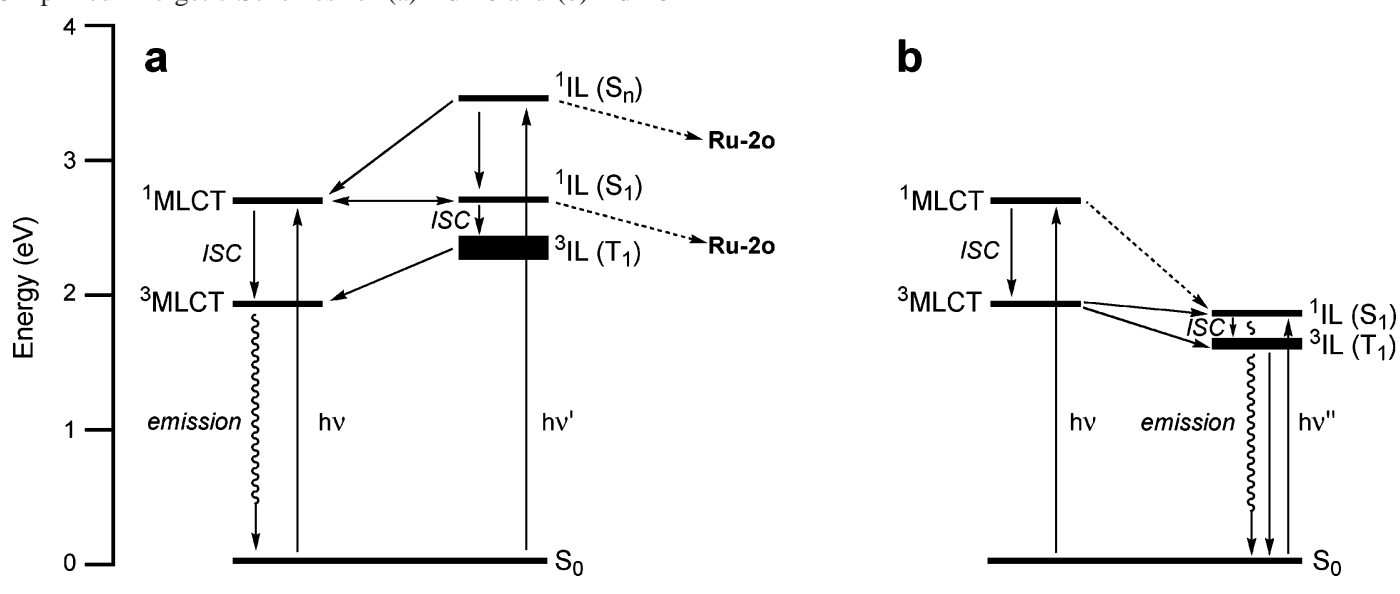

Scheme 5. Simplified Energetic Scheme for Os-2o

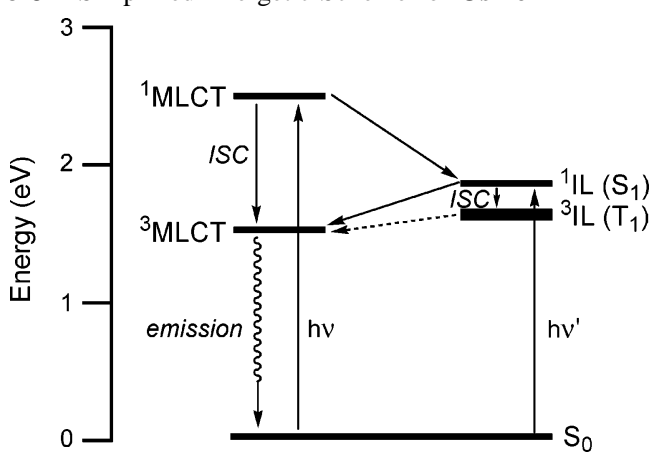

localized on the spiropyran moiety, in competition with this energy transfer process.

Based on the presented experimental results, a qualitative energy diagram for $\mathbf{R u - 2 c}$ is depicted in Scheme 4a. The energies of the lowest ${ }^{1} \mathrm{MLCT}$ and ${ }^{3} \mathrm{MLCT}$ states of the $[\mathrm{Ru}-$ $\left.(\text { bpy })_{3}\right]^{2+}$ fragment are derived from the UV-vis absorption and emission spectra, respectively. The energy of the spiropyran $\mathrm{S}_{1}$ level is taken from theoretical calculations in the literature. ${ }^{67}$ The data indicate that the $S_{0} \rightarrow S_{1}$ transition has zero oscillator strength and that the $S_{3}$ level is the lowest intraligand excited state that is optically accessible. Its energy has been derived from the UV-vis absorption spectrum. The energy of the intraligand $T_{1}$ level is not known exactly, but as discussed above, it must lie between the $S_{1}$ and ${ }^{3}$ MLCT levels. Formation of Ru-2o then occurs from the ${ }^{1} \mathrm{IL}$ states in competition with ISC and energy transfer to the MLCT levels.

The energetic scheme for Os-2c is qualitatively the same, only the MLCT excited states are lower in energy than the corresponding levels of Ru-2c.

Scheme 4b shows a qualitative energy diagram for $\mathbf{R u}-$ 2o. The energy of the lowest ${ }^{1} \mathrm{IL}$ level has been derived from the emission spectrum. The position of the ${ }^{1}$ MLCT absorption band does not shift with conversion, and the energy of the ${ }^{3}$ MLCT level should not be affected either. Also in this case, the intraligand $\mathrm{T}_{1}$ level is not known exactly, as already discussed in the emission properties, it must lie between the ${ }^{3}$ MLCT of the ruthenium and that of the osmium (1.62$1.96 \mathrm{eV})$.

For Os-2o, the energy diagram is quite different (see Scheme 5). From the UV-vis absorption spectrum, we can conclude that also in this case the lowest intraligand singlet state is lower in energy than the ${ }^{1}$ MLCT state. However, the fact that for Os-2o we observe ${ }^{3}$ MLCT emission with the same quantum efficiency as for Os-2c shows that in this case the ${ }^{3}$ MLCT state is the lowest-energy excited state of the system. As this state has partial singlet character, energy is transferred to the ${ }^{3} \mathrm{MLCT}$ from the ${ }^{1} \mathrm{IL}_{\mathrm{SP}}$ levels directly, and no open-form spiropyran emission is observed, even upon direct excitation to the lowest ${ }^{1} \mathrm{IL}$ level of the spiropyran subunit.

(83) Creutz, C.; Chou, M.; Netzel, T. L.; Okumura, M.; Sutin, N. J. Am. Chem. Soc. 1980, 102, 1309-1318. 


\section{Conclusions}

In this paper, we have combined luminescent $\left[\mathrm{Ru}(\mathrm{bpy})_{3}\right]^{2+}$ and $\left[\mathrm{Os}(\mathrm{bpy})_{3}\right]^{2+}$ metal complexes with photochromic nitrospiropyrans into one molecule, described their photophysical, photochemical, and electrochemical behavior and compared that with the free ligand and a reference compound.

The photochemical ring-opening process is less efficient for the metal complexes than for the noncoordinated ligand. In the closed-form ligand, both the fast singlet-state and the slower triplet-state ring-opening processes can occur. In contrast, these processes are quenched in the metal complexes by energy transfer to the lower-lying MLCT levels of the luminescent metal tris(bipyridine) chromophores. The singletstate photoreaction can compete with the energy transfer process, but the triplet state photoreaction is completely inhibited.

In the open form, the energy of the lowest triplet excited state of the spiropyran moiety lies conveniently between those of the ${ }^{3}$ MLCT levels of the ruthenium and osmium complexes, resulting in a metal-to-spiropyran energy transfer process for the ruthenium system and a converse process for the osmium complex. This finding represents the basis for the construction of more complicated systems in which the spiropyran is used as the bridging ligand between a donor and acceptor moiety to obtain large differences in the efficiency of energy transfer from donor to acceptor between the two forms.

The closed spiropyran species can also be converted electrochemically to the corresponding open merocyanine form by reduction and subsequent two-step reoxidation involving an unidentified intermediate structure. Interestingly, the efficiency of this process is not significantly affected by the metalation of the spiropyran moiety.

Acknowledgment. The assistance of Hendrik J. van Ramesdonk and Dick Bebelaar (University of Amsterdam) with time-resolved measurements and of Jan Meine Ernsting (University of Amsterdam) with low-temperature NMR experiments is gratefully acknowledged. We thank NWO and the EC (Contract No. G5RD-CT-2002-00776, MWFM) for financial support.

Supporting Information Available: Figure S1 showing the UV-vis spectra of complex Os-2c and its 1e- to 4e-reduced forms. This material is available free of charge via the Internet at http://pubs.acs.org.

IC0606680 